\title{
Pressure or Prudence? Tales of Market Pressure and Fiscal Adjustment
}




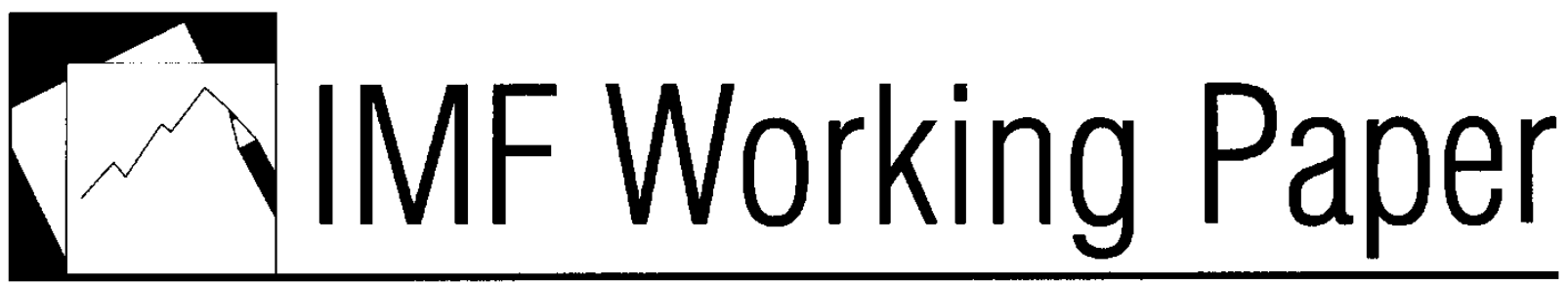

\section{Pressure or Prudence?}

Tales of Market Pressure and Fiscal Adjustment

Salvatore Dell'Erba, Todd Mattina and Agustin Roitman

INTERNATIONAL MONETARY FUND 


\title{
IMF Working Paper
}

Fiscal Affairs Department

\section{Pressure or Prudence? Tales of Market Pressure and Fiscal Adjustment}

\author{
Prepared by Salvatore Dell'Erba, Todd Mattina, and Agustin Roitman \\ Authorized for distribution by Abdelhak Senhadji
}

July 2013

\section{This Working Paper should not be reported as representing the views of the IMF.}

The views expressed in this Working Paper are those of the author(s) and do not necessarily represent those of the IMF or IMF policy. Working Papers describe research in progress by the author(s) and are published to elicit comments and to further debate.

\begin{abstract}
We study whether multiyear fiscal adjustment plans in 17 OECD countries during 1980-2011 have been associated with market pressure. We find that only a third ( 34 percent) of the consolidations occurred under market pressure, suggesting that market pressure is important but not the main element associated with consolidation plans. Many adjustments under market pressure were also clustered around external shocks, and entailed larger median fiscal adjustments than other multiyear consolidations. In contrast, we find that virtually all multiyear consolidations aimed at reducing budget deficits occurred with initially weak macro-fiscal fundamentals.
\end{abstract}

JEL Classification Numbers: E62, G12, H60

Keywords: market pressure; fiscal adjustment; fiscal consolidation; macro-fiscal fundamentals; OECD; advanced economies Authors’ E-Mail Address: SDellErba@imf.org; TMattina@imf.org; ARoitman@imf.org 


\section{Contents}

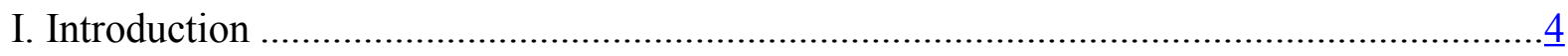

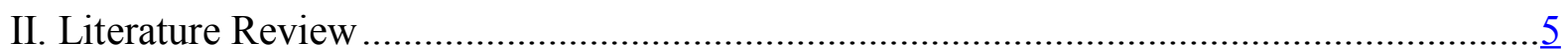

III. A Simple Model of Market Pressure and Fiscal Adjustment …........................................ 1

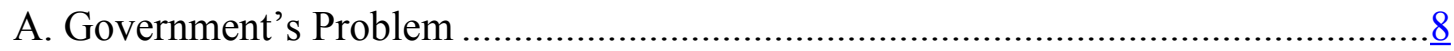

B. Implications of Default Risk .............................................................................

IV. Identification of Fiscal Adjustment and Measurement of Market Pressure ……………....10

A. Identification of Fiscal Adjustments .................................................................10

B. Identification and Measurement of Market Pressure ..............................................11

V. Fiscal Adjustments under Pressure: The Big Picture......................................................13

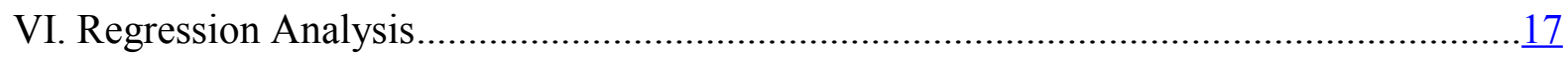

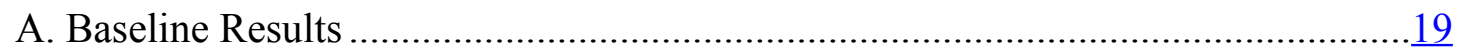

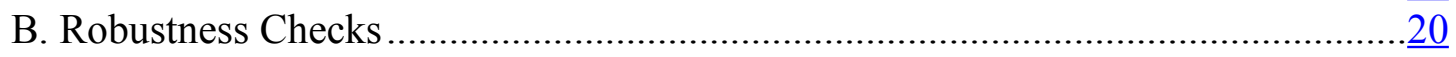

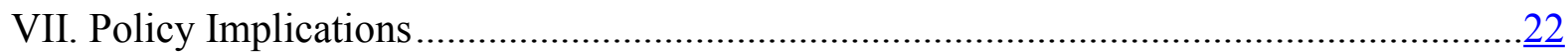

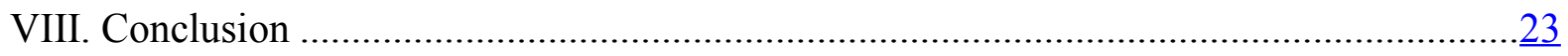

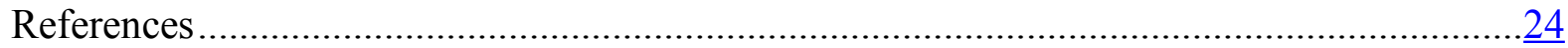

\section{Figures}

1. Market Pressure Indicators and Fiscal Consolidation Episodes, 1980-2011 .......................13

2. Multiyear Fiscal Consolidation Episodes and Market Pressure …................................14

3. Multiyear Fiscal Consolidation Episodes and External Shocks. ........................................15

4. Median Cumulative Fiscal Adjustment Based on Different Identification

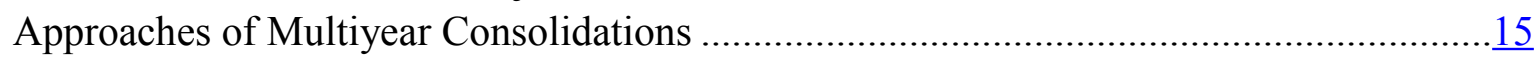

5. Fiscal Consolidation Episodes and Fiscal Fundamentals ................................................17

\section{Boxes}

1. Fiscal Plans versus Fiscal Outcomes: Identification and Measurement of Fiscal Policy ....... $\underline{6}$

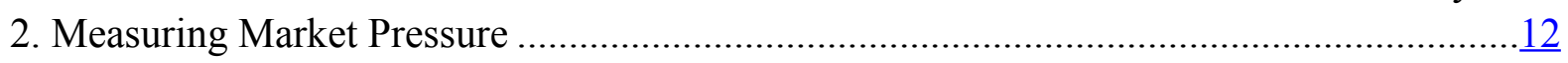

\section{Appendixes}

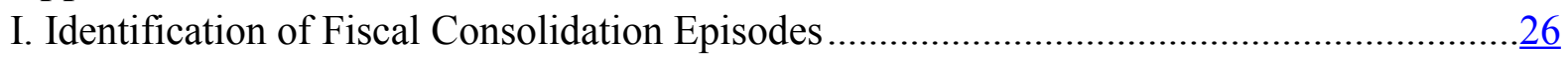



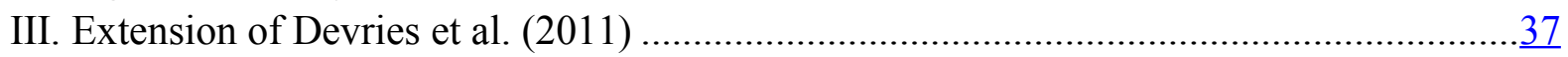

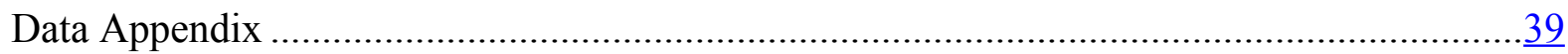




\section{Appendix Tables}

1. Planned Multiyear Consolidation Episodes Based on the Narrative Approach, 1980-2011.

2. Large Multiyear Consolidation Episodes Based on the "CAPB" Approach, 1980-2011.....

3. Summary Statistics

4. Regression Results of a Conditional Logit Panel Regression Model ……...........................

5. Different Indicators of Market Pressure

6. Different Identification of Market Pressure Episodes

7. Interaction of Market Pressure Indicators and Debt to GDP .34

8. Splitting the Sample $\underline{35}$

9. Determinants of a Consolidation Spell $\underline{.36}$

10. Extending the Action-Based Dataset on Discretionary Fiscal Consolidations, 2010-11 


\section{INTRODUCTION ${ }^{1}$}

This paper presents historical evidence on the association between market pressure and discretionary decisions to undertake multiyear fiscal consolidations. Many of the largest advanced economies may need to pursue sizable fiscal adjustments over the medium term to rebuild fiscal buffers following the global financial crisis. ${ }^{2}$ However, historically low borrowing rates and highly accommodative monetary policies have raised concerns that policymakers lack strong market-based incentives to pursue sustained consolidations. We explore this issue by assessing if multiyear fiscal consolidations in 17 OECD countries during the last 30 years have been associated with market pressure. We also consider the association between weak underlying macro-fiscal fundamentals with planned multiyear consolidations.

We identify multiyear fiscal adjustments based on a dataset of planned consolidations. Focusing on intended fiscal adjustments enables us to assess the potential link between market pressure and discretionary changes in fiscal policy. We measure market pressure based on changes in government short- and long-term interest rates, exchange rates and credit ratings. We also consider macroeconomic and fiscal fundamentals preceding and during the first year of a multiyear fiscal adjustment. Based on this approach, we find that 34 percent of planned multiyear consolidations in OECD countries during 1980-2011 occurred under market pressure, whereas virtually all episodes were associated with initially weak fundamentals, such as high debt, adverse debt dynamics or below trend growth. These results suggest that market pressure is important but not the main feature of multiyear fiscal consolidations.

We proceed as follows: Section II presents a brief literature review. Section III illustrates the link between market pressure and fiscal adjustment in a simple open-economy model. Section IV discusses the methodology used to (i) identify fiscal consolidation episodes, and (ii) identify and measure market pressure. Section V presents the main results on the relative importance of market pressure compared to other key macro-fiscal fundamentals and their association with multiyear fiscal consolidation plans. Section VI provides regression analysis to support the facts presented in Section V. In Section VII we discuss policy implications, and Section VIII concludes.

\footnotetext{
${ }^{1}$ Malin Hu and Nancy Tinoza provided excellent research assistance for this paper. The authors would also like to thank Carlo Cottarelli, Abdelhak Senhadji and participants of a research seminar in the Fiscal Affairs Department of the IMF for their helpful comments and insights. All remaining errors and omissions are our own.

${ }^{2}$ See IMF Fiscal Monitor: Fiscal Adjustment in an Uncertain World (April 2013):

(http://www.imf.org/external/pubs/ft/fm/2013/01/fmindex.htm).
} 


\section{LiterATURE REVIEW}

The large literature on the analysis of episodes of fiscal consolidations can be divided into two main strands. One strand has focused on the conditions that lead countries to begin a consolidation; the other strand has focused on the macroeconomic and financial consequences of fiscal consolidations. ${ }^{3}$ Our paper falls into the first strand of analysis. This paper differs from the previous literature in two main aspects. First, we use a novel dataset constructed by Devries et al. (2011) which allows us to identify discretionary multiyear fiscal consolidations based on policy actions rather than policy outcomes. Second, this is the first paper to analyze how the emergence of market pressure is associated with the likelihood of beginning a discretionary fiscal consolidation. Our question and results do not directly contribute to the literature analyzing determinants of successful consolidations. ${ }^{4}$ The literature has identified several factors that lead countries to initiate a fiscal consolidation. ${ }^{5}$ The consensus among those studies is that consolidations are more likely to start when initial fiscal conditions are weak and governments are stronger and newly elected. Molnar (2012) finds that conditions like the initial size of the budget deficit, newly elected governments or governments with a larger majority are factors that tend to increase the likelihood of a consolidation. Similarly, Guichard et al. (2007) finds that consolidations are more likely after an election year or when the cyclically adjusted primary balance (CAPB) is weak.

While previous studies have relied on statistical methods to identify episodes of fiscal consolidation based on changes in the CAPB, in this paper we identify a discretionary consolidation episode using an alternative approach based on intended or "action-based" plans. We use the dataset constructed by Devries et al. (2011) who follow the narrative approach originally developed by Romer and Romer (2009) to document episodes of discretionary fiscal policy changes in 17 OECD countries during 1973-2009 based on a reading of official documents and reports. This identification approach represents an alternative way to identify and measure discretionary changes in fiscal policy (Box 1).

On the relation between fiscal policy and financial markets behavior, Ardagna (2009) finds that long-term government interest rates decrease when fiscal positions improve, and increase around periods of budget deterioration. Stock market prices also tend to surge around times of substantial fiscal tightening and plunge in periods of loose fiscal policy. In contrast to Ardagna (2009), we focus on "action-based" multiyear adjustment episodes in order to

\footnotetext{
${ }^{3}$ See Alesina and Perotti (1995), Alesina and Ardagna (1998), and Ardagna (2009). See Guajardo et al. (2012) for more recent evidence on the macroeconomic effects of fiscal consolidations and its relation to the previous literature.

${ }^{4}$ See Kumar et al. (2007) for a review of the literature on the determinants of successful consolidations.

${ }^{5}$ See Molnar (2012) for a thorough literature review on the factors that affect the start of consolidations.
} 
capture fiscal adjustment plans (as opposed to fiscal adjustment outcomes). Second, we do not focus on the reactions of financial markets to fiscal consolidations, but rather on the reactions of policy makers to developments in the financial markets.

\section{Box 1. Fiscal Plans versus Fiscal Outcomes: Identification and Measurement of Fiscal Policy}

In order to analyze fiscal adjustments, it is crucial to identify discretionary fiscal policy changes appropriately based on policy instruments (as opposed to policy outcomes). ${ }^{1}$ The traditional approach to estimate discretionary fiscal policy changes has focused on the CAPB. ${ }^{2}$ An alternative approach pioneered by Romer and Romer (2010) is the so called 'narrative approach' which relies on fiscal plans, as announced in budgets, as well as other official documents. ${ }^{3}$ This box summarizes the advantages and disadvantages of both approaches for identifying and measuring discretionary changes in fiscal policy.

By 'adjusting' for the business cycle, the traditional approach relies on an estimated CAPB, which in principle reflects changes in discretionary policy rather than the economic cycle. Hence, during booms (recessions), the CAPB would be lower (higher) than the actual primary balance, as it excludes cyclical improvements (deteriorations) that are not related to active policy actions. This approach has at least three fundamental weaknesses. First, as noted by Riera-Crichton et al. (2012) it attributes 'the residual' (after the cyclical adjustment) to fiscal policy instruments, hence overestimating and overcounting discretionary fiscal policy changes. Second, the estimation of potential output, which plays a crucial role in the cyclical adjustment, varies considerably depending on the particular statistical technique used for its calculation. Third, revenue and expenditure elasticities are usually assumed to be time invariant.

By relying on official documents (i.e., budgets, laws, etc.) the 'narrative approach' seeks to identify discretionary fiscal policy changes based on official announcements and policymakers' plans. In principle, this approach enables one to identify pure fiscal policy actions based on policy instruments (as opposed to fiscal outcomes). This approach has at least two drawbacks. First, as pointed out by Perotti (2012), it is essential to consider all official announcements and plans (i.e., supplementary budgets), otherwise mismeasurement could easily arise. Second, even if discretionary measures are announced, implementation will not always follow as planned.

In terms of measurement, it is easy to show that the traditional approach would tend to overestimate fiscal policy changes if it does not take into account other factors (i.e., asset and commodity prices, exchange rates, etc). By contrast, the narrative approach is well suited to identify intended discretionary changes; but it does not indicate if the announced policy changes were actually implemented and executed as planned.

For our purposes, and given that our main focus is not on the intended size of fiscal consolidation plans, but on whether policy makers could potentially respond to market pressure, the drawbacks associated with the narrative approach are not applicable to our research question. Consequently, the narrative approach remains an appropriate and better way to identify intended policy actions compared to the traditional CAPB approach.

1/ Kaminsky et al. (2004).

2/ Alesina and Ardagna (1998 and 2009), and Alesina (2010).

3/ Devries et al. (2011). 
Recent papers have also investigated how fiscal variables react to changes in the debt service burden. Based on a structural VAR analysis, de Groot et al. (2012) find that the primary balance responds positively to interest payment shocks, although with delays. Similarly, Mauro et al. (2013), and Debrun and Kinda (2013) analyze the relationship between the primary balance and interest payments. Extending the Bohn equation to include indicators of the interest cost burden, they find that higher borrowing costs are associated with more pronounced fiscal consolidation. Our paper differs from these studies since our focus is on whether countries consolidate or not under the emergence of market pressure, rather than by how much. ${ }^{6}$

Our paper focuses on the question of whether market pressure is a necessary condition for a discretionary consolidation. The issue is similar to the one discussed in Bergman et al. (2013) who analyze whether signals of market pressure can be considered reliable to induce sound public finances. The authors present empirical evidence on the relationship between market pressure, fiscal rules, and fiscal sustainability. By focusing on the reaction of CDS spreads during the period 2001-2012 to a broad set of news announcements, they find that the quality of market signals is insufficient to guide fiscal policy decisions. They conclude that strong institutions like fiscal rules provide more reliable incentives to maintain sound public finances. In contrast to that paper, we address the issue by looking instead at how often we observe market pressure conditional on observing a discretionary multiyear fiscal consolidation.

\section{A Simple Model of Market Pressure And Fiscal AdJustment}

This section outlines a simple model following $\mathrm{Vegh}^{7}$ that illustrates the link between market pressure (i.e., interest rates) and fiscal consolidation. It is not our objective to 'test' this model, as we use it as a conceptual framework to think about the potential link between market pressure and fiscal consolidation in Section IV. In this model, higher interest rates imply the need for fiscal consolidation so that the government respects its intertemporal budget constraint. Since creditors only lend to a government up to the point where it remains optimal to repay its liabilities rather than default, there is no default in equilibrium. A key implication is that an increase in interest rates or weaker debt dynamics implies the need for an adjustment to avoid default.

\footnotetext{
${ }^{6}$ In Section V of the paper, we find that our descriptive evidence is broadly in line with the findings of these papers.

${ }^{7}$ See Vegh, forthcoming (MIT Press). http://econweb.umd.edu/ vegh/book/book.htm
} 


\section{A. Government's Problem}

We focus on a two-period small open-economy model with perfectly integrated world goods and capital markets. The government's lifetime welfare function is given by:

$$
W=u\left(g_{1}\right)+\beta u\left(g_{2}\right)
$$

where $\beta$ is the subjective discount factor, and $g_{1}$ and $g_{2}$ denote government spending in periods 1 and 2, respectively. ${ }^{8}$ The flow budget constraints are given by:

$$
\begin{aligned}
& b_{1}=r_{1}-g_{1} \\
& g_{2}=(1+\rho) b_{1}+r_{2}
\end{aligned}
$$

where $r_{1}$ and $r_{2}$ denote government revenues in periods 1 and 2, respectively; $g_{1}$ and $g_{2}$ denote government consumption in periods 1 and 2 , respectively; $b_{1}$ is the net foreign asset position of the government; and $\rho$ represents the real interest rate. For simplicity, we assume that government revenues are given exogenously, and the policymaker chooses the spending path to maximize welfare W. Since this is an open-economy model, the government can borrow in the first period to smooth spending over time. The government's intertemporal budget constraint is given by:

$$
r_{1}+\frac{1}{1+\rho} r_{2}=g_{1}+\frac{1}{1+\rho} g_{2}
$$

Solving the maximization problem, the first-order conditions imply that $g_{1}=g_{2}=g^{9}$ or more precisely:

$$
g=\frac{1+\rho}{2+\rho}\left(r_{1}+\frac{1}{1+\rho} r_{2}\right)
$$

If $r_{1}<r_{2}$, then the optimal response is for the government to borrow in period 1 .

$$
b_{1}=\frac{r_{1}-r_{2}}{2+\rho}<0
$$

\footnotetext{
${ }^{8}$ We assume standard preferences (concave, continuous, and twice continuously differentiable utility functions), and discount rate equal to the interest rate (i.e., $\beta(1+\rho)=1$ ).

${ }^{9}$ Formally, the maximization problem consists in choosing $g_{1}$ and $g_{2}$ to maximize (1) subject to (4).
} 
Defining net debt as $d_{1} \equiv-b_{1}$,

$$
d_{1}=-\frac{r_{1}-r_{2}}{2+\rho}>0
$$

A credible commitment mechanism implies that the government repays its debt plus interest in period 2. Government spending in period 2 is then given by $g_{2}=r_{2}-(1+\rho) d_{1}<r_{2}{ }^{10}$

\section{B. Implications of Default Risk}

The government will repay its debt if the cost of defaulting is larger than the cost of repaying its liabilities. Assume for simplicity that if a government decides to default then it will lose a fraction $\theta$ of its revenues for a given $0 \leq \theta \leq 1 .{ }^{11}$ In this stylized framework, the government will repay its debt if and only if:

$$
(1+\rho) d_{1} \leq \theta r_{2}
$$

or, equivalently

$$
r_{2}-(1+\rho) d_{1} \geq(1-\theta) r_{2}
$$

Intuitively, equation (9) indicates that government spending without default is higher than spending with default. This equation can be rearranged as follows:

$$
d_{1} \leq \frac{\theta r_{2}}{(1+\rho)}
$$

This condition implies that no creditor would lend more than $\frac{\theta r_{2}}{(1+\rho)}$. Hence, in this model, the government can borrow as much as needed up to $d_{1}$, where the supply of funds becomes perfectly inelastic. If equation (10) is binding, the government borrows up to its limit and government spending becomes pro-cyclical. Equation (10) also illustrates that market pressure (i.e., sovereign risk as captured in the interest rate) can affect the debt threshold and government spending. Changes in interest rates or fundamentals (i.e., growth and fiscal revenues) can have a material effect on borrowing capacity, imposing tighter constraints on

\footnotetext{
${ }^{10}$ If a credible commitment device to repay the debt is unavailable (i.e., there are no costs to default), then the government would be better off by defaulting on its debt incurred in period 1 and spending all revenues in period 2. Rational creditors anticipate this outcome and would not lend in period 1 in the absence of a precommitment mechanism to repay the debt, implying that the economy would be confined to financial autarky and a pro-cyclical fiscal stance.
}

${ }^{11}$ Default costs could include trade 'sanctions' by creditors, which could directly affect fiscal revenues. 
borrowing when it is most needed (i.e., in bad times). Given the direct link between market pressure and a government's ability to borrow, fiscal consolidation is required if financing conditions deteriorate and default is not an option. ${ }^{12}$

\section{IdENTIFICATION OF FisCAL AdJUSTMENT ANd MEASUREMENT OF Market Pressure}

\section{A. Identification of Fiscal Adjustments}

Multiyear fiscal consolidations are identified using a "narrative" approach based on the stated objectives of policy makers. As discussed in Section II, the literature traditionally identifies discretionary fiscal adjustments based on large changes in the CAPB.$^{13}$ This approach is not well suited to identify multiyear consolidation programs that typically involve smaller annual fiscal adjustments. As a result, we identify planned consolidations based on a narrative dataset involving planned adjustments to reduce high budget deficits. This approach produces 53 planned consolidation episodes during 1980-2011 (Appendix I).

The narrative approach is well suited to identify discretionary fiscal policy (Box 1). We follow Devries et al. (2011) to cover "action-based" or planned fiscal consolidations in 17 OECD countries during 1973 to 2009 and extend their dataset to $2011 .{ }^{14}$ According to Devries et al. (2011), action-based fiscal consolidations are motivated exclusively by a stated goal of reducing high budget deficits. The dataset measures planned fiscal adjustments recorded on an annual basis based on the intended implementation of measures. The narrative approach is free of statistical measurement problems associated with particular techniques needed to compute the cyclical adjustment. However, it is also important to note that the narrative approach is not free of problems, and might be subject to potential mismeasurement errors related to the size of discretionary policy changes, and subjective interpretation of stated policy goals. ${ }^{15}$ For our purposes, this issue is less concerning since our main focus is on the relative importance of possible triggers to undertakea fiscal consolidation.

\footnotetext{
${ }^{12}$ Notice that in this stylized model the supply of funds is kinked at $d_{1}$. One way of obtaining an upwardsloping supply of funds is to introduce uncertainty following Sachs and Cohen (1982).

${ }^{13}$ See Alesina and Ardagna (1998), Guichard et al. (2007), and Alesina and Ardagna (2010) for the CAPB approach. This approach has important limitations, such as failing to control for asset and commodity price cycles and imprecisely measured output gaps. Another approach follows Blanchard and Perotti (2002) in identifying structural vector autoregressions.

${ }^{14}$ We extend the dataset produced by Devries et al. (2011) to 2011 based on "action-based" or planned fiscal
consolidations in 17 OECD countries during 1973 to 2009. See Appendix III for details.

${ }^{15}$ For a detailed analysis, and evidence on mismeasurement problems see Perotti (2012).
} 
The narrative approach is also well suited to identify multiyear fiscal adjustments. We do not consider annual discretionary policy changes as separate and independent episodes. Contrary to Devries et al. (2011), we consider consecutive annual adjustments to be a single consolidation episode for two key reasons. ${ }^{16}$ First, consecutive discretionary policy changes are not necessarily independent since they could be components of a gradual multiyear adjustment program. Hence, treating each annual discretionary change reported in Devries et al. (2011) as an independent and separate fiscal consolidation could be potentially misleading. Second, treating consecutive yearly discretionary changes as independent events poses an identification problem. For instance, the initial conditions of one annual episode could be contemporaneous for the preceding episode. Appendix I provides additional details on the identification of multiyear episodes, and Appendix III outlines an extension of the dataset produced by Devries et al. (2011) from 2009 to 2011.

\section{B. Identification and Measurement of Market Pressure}

We identify market pressure based on multiple indicators. The simplest metric of market pressure is the correlation between long-term government interest rates and public debt ratios. Despite a secular increase in debt ratios, long-term interest rates fell throughout this period, suggesting modest market pressure. In this context, we focus on shorter term indicators of market pressure that occurred during this secular decline in interest rates. Changes in sovereign CDS spreads are a natural metric of an increased sovereign risk premium arising from market pressure. However, CDS securities only began trading widely for most countries from the early- to mid-2000s, and with limited liquidity in many cases. In the absence of a pure measure of sovereign credit risk since 1980, we consider a number of alternatives, including statistically large changes in 3-month and 10-year government interest rates. However, interest rates are imperfect measures of credit risk because higher borrowing rates can stem from higher expected inflation and currency risk. Consequently, we also consider negative changes in sovereign credit ratings and large currency depreciations as complementary indicators of market pressure (Appendix I, and Box 2).

Aside from the recent euro area crisis, advanced economies experienced relatively few market crises since $1980 .{ }^{17}$ However, periods of relative market stress compared to a country's own history have occurred more frequently. Our methodology for identifying market pressure involves expressing changes in monthly short- and long-term government interest rates and currency changes as a z-score relative to a three-year moving window. Specifically, the mean and volatility of changes in the indicators are calculated over a threeyear moving window of monthly data. Market pressure is considered to have taken place if the following two criteria are satisfied: (i) the z-score of monthly changes exceeds 2

\footnotetext{
${ }^{16}$ For details on the specific definition and selection criteria of the consolidation episodes see Appendix I.

${ }^{17}$ The main exceptions include Sweden's banking crisis in 1993, and the ERM crisis in 1992.
} 
representing a two-standard deviation shock; and (ii) the monthly change is in the upper 25th percentile of the cross-section of monthly changes of all 17 countries. A dummy indicator also takes a value of 1 if there are negative changes in the credit rating or outlook assigned by either Standard \& Poor's or Moody's. Box 2 outlines the precise formulation of these indicators in more detail. For the statistical analysis, we assess the association of a multiyear fiscal consolidation with each of the three categories of market pressure separately. As the three categories provide complementary information, we also evaluate the link between two out of three categories occurring with a discretionary multiyear consolidation.

\section{Box 2. Measuring Market Pressure}

We define three broad categories of market pressure, including government interest rates, currencies and credit ratings. Monthly z-scores, denoted as $z_{t}^{j}$, are computed for each country $\mathrm{j}$ for the following indicators denoted by $x_{t}^{j}$ in the equation below: the change in 3-month T-bill and 10-year bond yields; and changes in average monthly spot exchange rates relative to the U.S. dollar. ${ }^{1}$

$$
z_{t}^{j}=\frac{\left(x_{t}^{j}-\bar{x}\right)}{\sigma_{t}^{j}}
$$

The average and standard deviation of changes in the financial indicators, denoted as $\bar{x}$ and $\sigma$, respectively, are calculated based on a rolling 36-month window. For interest rates and currencies, market pressure occurs if two criteria are satisfied: the monthly z-score of an indicator exceeds two in the 12-month period before or concurrent with the beginning of a multiyear consolidation episode (i.e., in annual periods denoted by $\mathrm{t}-1$ and $\mathrm{t}$ ); and the monthly change is in the upper 25th percentile of the cross-section of monthly changes in all 17 countries. The rationale for the first criterion is to identify large monthly changes relative to a country's own history. The second criterion identifies large changes relative to other countries in the sample on each date $t$. Given our focus on market pressure, the indicators are constructed to focus only on large increases in interest rates and currency depreciations.

The main advantage of this approach is that it scales fluctuations consistently across countries (e.g., a given change in Japanese interest rates could be modest for higher interest rate countries). The 36-month moving window was selected to strike a balance between a stable trend to assess jumps, and allowing for a gradual adjustment of the trend given the secular decline in interest rates since the early 1980s.

Additional indicators of market pressure are based on the actions taken by credit rating agencies. The first indicator takes a value of one if either Standard \& Poor's or Moody's downgraded a government's long-term sovereign credit rating. The second indicator take a value of one in the event that either agency places the sovereign credit on a negative outlook. Consistent with the currency and interest rate indicators, market pressure is considered to have occurred if the indicators take a value of one in the year before or concurrent with the beginning of a multiyear consolidation episode (i.e., in year $\mathrm{t}-1$ or $\mathrm{t}$ ). 


\section{Fiscal Adjustments under Pressure: The Big Picture}

The decision to undertake a multiyear fiscal consolidation may reflect a reaction to market pressure or pre-emptive action to address weak underlying fundamentals. We find evidence suggesting that both channels were at play in OECD countries during 1980-2011. We begin by characterizing the economic and financial environment at the time of planned fiscal consolidations. We focus on the market pressure indicators described above and fundamental variables that are closely related to fiscal sustainability. Specifically, we consider the primary fiscal gap,${ }^{18}$ public debt as a share of GDP, and the primary fiscal deficit as a share of GDP.

Market pressure was not broadly associated with planned multiyear consolidation episodes. Signals of market pressure were observed in 20 to 48 percent of the planned multiyear consolidations depending on the specific indicator (Figure 1). This compares with signals of market pressure in just 8 percent of years without a decision to undertake a multiyear fiscal consolidation. Changes in short-term interest rates were most commonly associated with planned consolidations. Consistent with our multiple indicator approach, we classify a multiyear consolidation as occurring under market pressure if two out of the three indicators are elevated. Figure 2 highlights that approximately 34 percent of the multiyear consolidations took place under market pressure based on this definition.

Figure 1. Market Pressure Indicators and Fiscal Consolidation Episodes, 1980-2011 (in percentage points of GDP, and percent respectively)

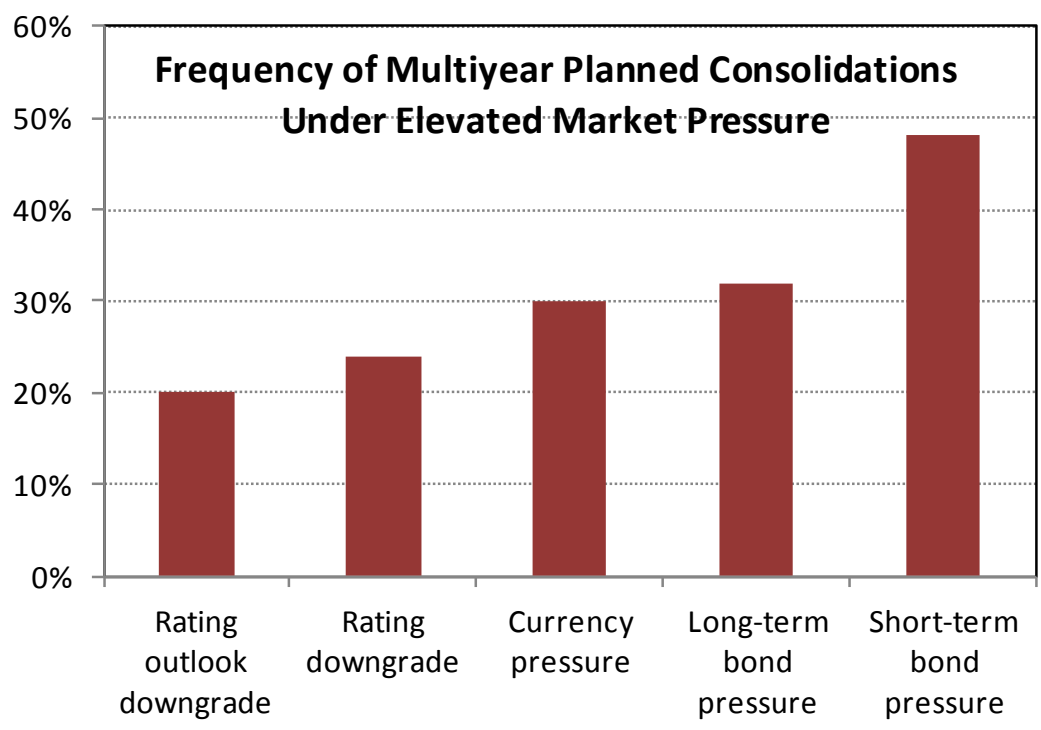

Sources: IMF staff estimates based on IFS, S\&P and Moody's.

\footnotetext{
${ }^{18}$ Primary gaps are defined as the debt-stabilizing primary balance minus the actual primary balance. This metric indicates the required adjustment to stabilize the debt at its current level as a share of GDP. See the Data Appendix for further details.
} 


\section{Figure 2. Multiyear Fiscal Consolidation Episodes and Market Pressure 1/}



Sources: Devries and others (2011), Bloomberg, Datastream, and IMF staff estimates.

1/ Each circle contains the episodes of multiyear fiscal consolidation that are preceded or accompanied by market pressure. Episodes in red font flag episodes that satisfy at least two market pressure indicators.

Many consolidations that occurred under market pressure were a response to a global shock or financial dislocation, and entailed a larger fiscal adjustment on average. These episodes occurred in three broad clusters: the Volcker disinflation of the early 1980s; the ERM crisis and global bond bear market in the early-to-mid 1990s; and the recent euro area crisis (Figure 3). Consequently, it remains unclear that these consolidations were triggered by market pressure to discipline unsustainable borrowing or other factors related to the external shock. However, the median cumulative fiscal consolidation of episodes under market pressure is significantly larger than other consolidation episodes (Figure 4). ${ }^{19}$ These results underscore that market pressure can result in potentially abrupt and large fiscal adjustments when they do occur, and also that these adjustments could be partly due to external factors and exogenous variables (i.e., exchange rates) unrelated to discretionary fiscal policy.

\footnotetext{
${ }^{19}$ We compare the average size of multiyear consolidations based on two distinct datasets given limitations in both approaches. Perotti (2012) argues that the narrative dataset excludes supplementary budgets that unwound part of the intended consolidations. Perotti (2012) also recognized statistical problems with the CAPB approach.
} 
Figure 3. Multiyear Fiscal Consolidation Episodes and External Shocks

(share of countries in a multiyear fiscal consolidation, in percent)

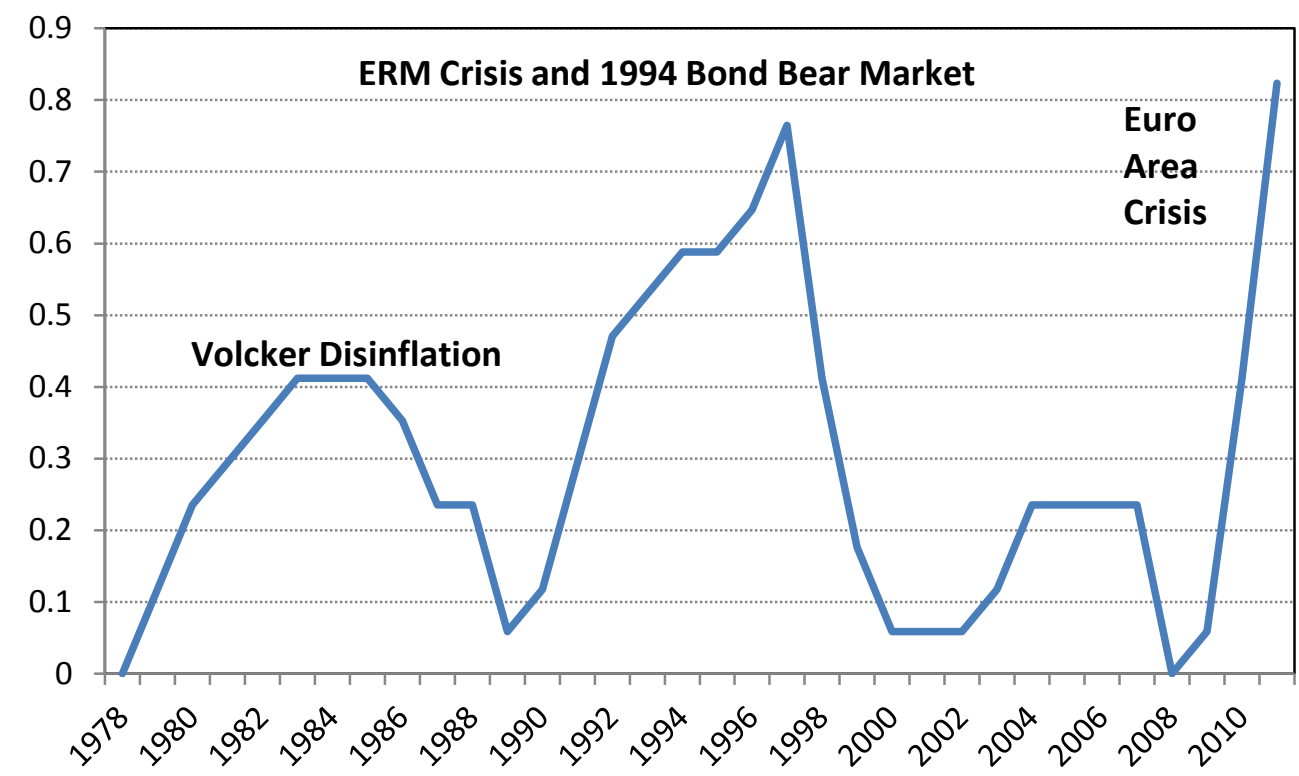

Source: IMF staff estimates based on Devries et al. (2011).

Figure 4. Median Cumulative Fiscal Adjustment Based on Different Identification Approaches of Multiyear Consolidations $1 /$

(in percentage points of GDP)

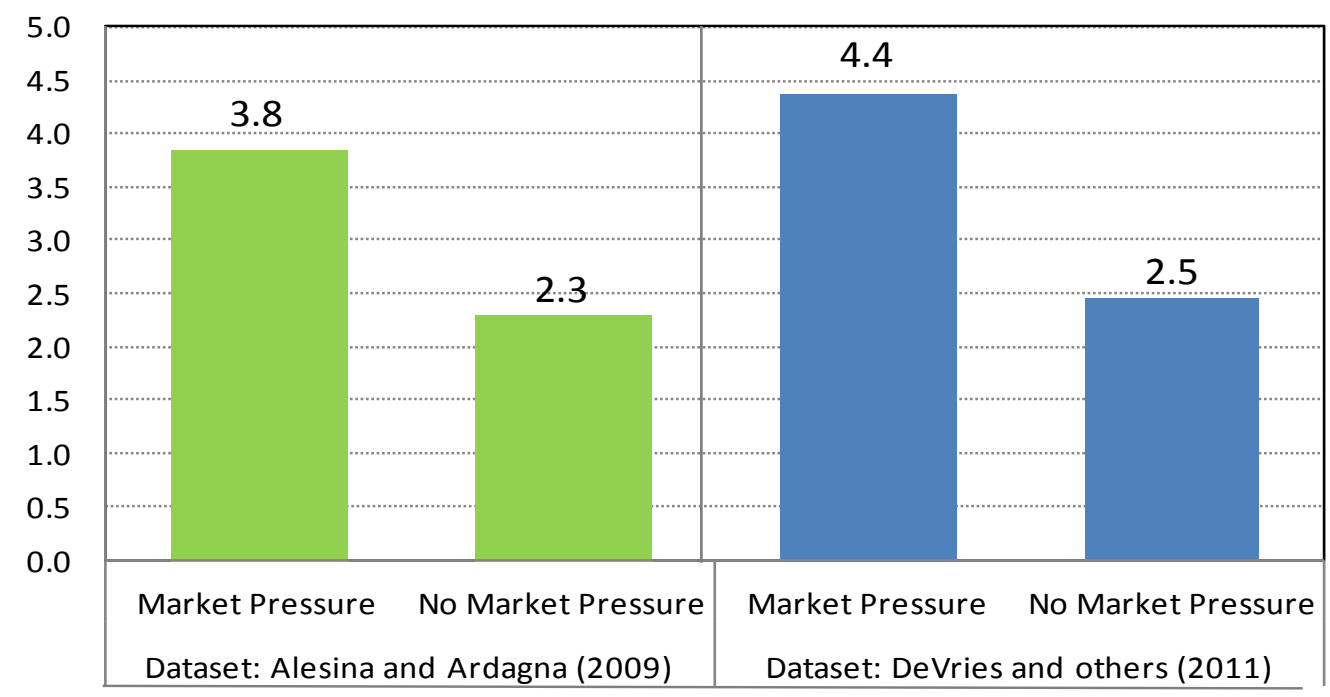

Sources: Alesina and Ardagna (2009); Devries and others (2011); and IMF staff estimates.

$1 /$ Both panels compare the median cumulative fiscal adjustment in a consolidation program for episodes under market pressure versus episodes that are not under pressure. The left panel is based on the change in the CAPB using the dataset of Alesina and Ardagna (2009). The right panel is based on the narrative dataset of Devries and others (2011). 
Planned multiyear consolidations were generally associated with initially weak macroeconomic and fiscal fundamentals. While many potential fundamentals could be considered, we focus on three indicators related to sovereign debt vulnerability: the primary fiscal gap, the public debt ratio, and the output gap. A positive fiscal gap implies debt dynamics are unsustainable since an unchanged fiscal stance would result in a rising debt ratio over time.$^{20}$ High debt ratios imply limited fiscal room for maneuver following shocks. We classify debt ratios exceeding 60 percent of GDP with increased vulnerability. Finally, we look at economic activity below trend since output gaps reduce fiscal revenues, result in adverse debt dynamics and are correlated with credit risk.

Almost all multiyear consolidations occurred in the context of weak underlying fundamentals. In the universe of 53 multiyear consolidations, three quarters ( 73 percent) of the episodes were associated with weak fundamentals in two out of three indicators (Figure 5). Figure 5 shows that most consolidations occurring under market pressure also had multiple sources of weak fundamentals.

${ }^{20}$ A positive primary gap could be sustainable for limited periods in countries with ample fiscal buffers, although fiscal adjustment would be needed at some stage. 
Figure 5. Fiscal Consolidation Episodes and Fiscal Fundamentals 1/

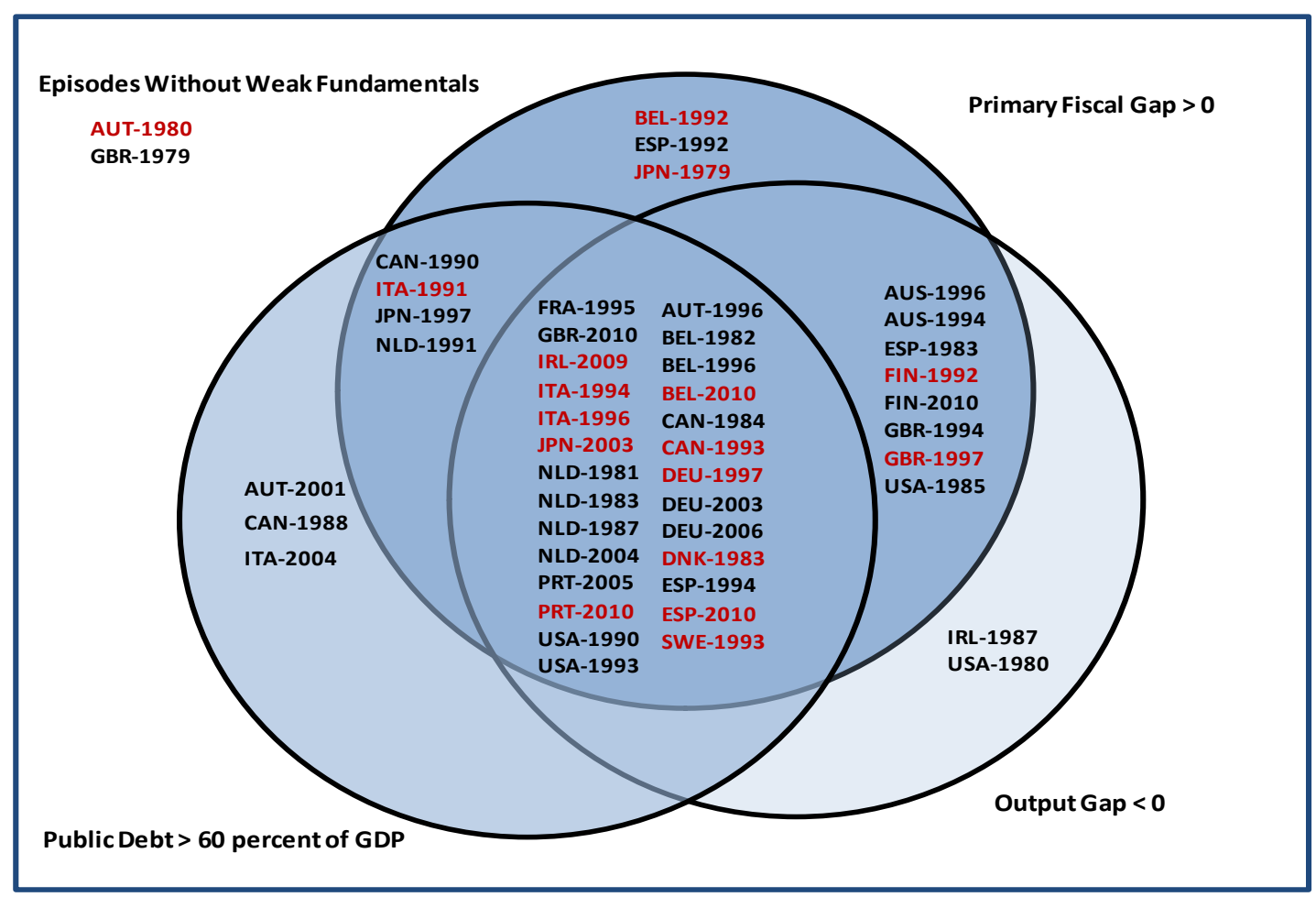

Sources: Devries and others (2011), Bloomberg, Datastream, and IMF staff estimates

1/ The table shows the consolidation episodes associated with weak fundamentals: sovereign debt above 60 percent of GDP; a positive primary gap; and a negative output gap. Each circle reports the adjustment episodes that are associated with the criterion in the year of the consolidation. The episodes in red font are associated with market pressure. A limited number of episodes are excluded owing to data constraints.

\section{Regression ANALYSIS}

To assess the relative importance of potential triggers of fiscal consolidations, we test the correlation of market pressure indicators versus fiscal fundamentals in the 12 months preceding a decision to consolidate. We, thus, estimate the following equation:

$$
\operatorname{Pr}\left(\text { Cons }_{i t}=1\right)=\alpha_{i}+\gamma_{t}+\sum_{j=1}^{N} \delta_{j} F_{j i, t-1}+\sum_{l=1}^{Z} \beta_{l} \mathrm{M} P_{l i, t-1}+\sum_{k=1}^{H} \theta_{k} X_{k i, t}+\varepsilon_{i t}
$$

where the dependent variable is a dummy indicator that assumes a value of 1 at the beginning of a multiyear consolidation episode and 0 otherwise for country $i=1, \ldots, N$ in year $t=1, \ldots, T$; $F_{j i, t-1}$ represents a matrix of the previous year's $N$ fiscal fundamentals; $\mathrm{M} P_{l i, t-1}$ is a matrix containing our $Z$ constructed market pressure indicators for country $i$ in year $t-1 ; X_{k i, t}$ is a matrix 
containing additional control variables that explain the decision to start a fiscal consolidation in a given year. In the panel estimation we include country $\left(\alpha_{i}\right)$ and time-specific $\left(\gamma_{t}\right)$ fixed effects. Since we are interested in whether market pressure triggers consolidations, our dependent variable corresponds to the probability of beginning a consolidation. ${ }^{21}$ The estimation method is a conditional logit model with coefficient estimates interpreted as "odds ratios," which are defined as the likelihood of undertaking a multiyear consolidation divided by the probability of not starting a consolidation. In this way, a coefficient over 1 implies that beginning a multiyear consolidation is more likely.

It is important to identify appropriately the timing of the market pressure events with respect to the timing of the fiscal consolidation episodes. As elaborated in Box 2, we evaluate monthly indicators of market pressure in the preceding year of a fiscal consolidation. Another important issue is the timing of fiscal years, which differs across countries. Since the fiscal year does not necessarily follow the calendar year, it is important to attribute correctly the emergence of market pressure to the appropriate budget cycle. ${ }^{22} \mathrm{We}$ adopt the timing approach of Alesina et al. (1998) who study the impact of fiscal consolidations on political change. They assume that the fiscal budget is discussed in the second part of the calendar year. Under this assumption, every market pressure episode that occurs between July 1 of year $t$ and June 30 of year $t+1$ is considered contemporaneous to the calendar year $t$ and thus associated to the fiscal consolidation of year $t$. For example, in our regression framework, the occurrence of market pressure between July 1 in 1995 and June 30 in 1996 will be associated with the decision to consolidate in year 1995. ${ }^{23}$ The market pressure indicator will be coded as 1 if in any month occurring over the relevant fiscal year the conditions highlighted in Box 2 are respected. ${ }^{24}$

In the baseline model we include the following variables:

\footnotetext{
${ }^{21}$ Since our episodes are multiyear consolidations, as a robustness check we also look at the probability of a country being in a consolidation episode. The results are broadly unchanged.

${ }^{22}$ In Section V, we presented results focusing on the occurrence of market pressure over fiscal year $\mathrm{t}-1$ and $\mathrm{t}$, thus preceding or coinciding with the start of a consolidation episode. To avoid the potential problem of reverse causality stemming from fiscal consolidation leading to market pressure, in this section we focus on the impact of initial conditions in affecting the probability of a consolidation.

${ }^{23}$ The countries in our sample which do not follow the convention of Alesina et al. (1998) are: Australia (July 1-June 30), Canada (April 1-March 31), Japan (April 1-March 31), the United Kingdom (April 1-March 31), the United States (October 1-September 30). For the other countries in the sample, we perform sensitivity analyses with respect to the definition of the fiscal year and find that the main results do not change.

${ }^{24}$ Aggregating over the number of months which fulfill the conditions in Box 2 does not alter the results.
} 
- Initial fiscal policy conditions and debt sustainability: indicators include the debt-toGDP ratio, the primary balance as a share of GDP, and the debt-stabilizing primary balance as a share of GDP;

- Initial monetary policy stance: we include an indicator on the level of the ex-post shortterm real interest rate as a proxy for the monetary policy stance, ${ }^{25}$

- Initial macroeconomic conditions: indicators include the output gap as a share of potential GDP and the external current account balance as a share of GDP;

- Political-economy factors: indicators include a dummy variable for a legislative election occurring in year t or year t-1; a political polarization dummy; ${ }^{26}$ a variable which captures the number of years the government has left in the current term; and a dummy equal to 1 if the country has a fiscal rule. ${ }^{27}$

All equations are estimated using an annual data sample covering the period 1980-2011 for 17 OECD countries. Tables reporting the summary statistics of our variables and the regression results are reported in Appendix II, and data sources are outlined in the Data Appendix.

\section{A. Baseline Results}

Appendix II, Table 4 presents the results based on the regression model outlined above. The baseline results presented in column (1) exclude the market pressure indicators. The results suggest that a 1-percent increase in the primary balance ratio decreases the odds of beginning a consolidation by about 36 percent, while a 1-percent increase in the debt-stabilizing primary balance ratio increases the odds by about 24 percent. Somewhat surprisingly, the initial debt ratio and the initial macroeconomic conditions are insignificantly associated with the beginning of a multiyear consolidation, although we find that a positive output gap in the previous year is more likely to spur a consolidation. These results are in line with the previous literature, which find insignificant results on the public debt coefficient (Molnar 2012), and a positive association between consolidation and the output gap (von Hagen and Strauch 2001, and European Commission 2007). Political factors are also important, especially the recent occurrence of an election. Political polarization is insignificant, although the results suggest that a decrease in

\footnotetext{
${ }^{25}$ See von Hagen and Strauch (2001) who construct an index of monetary policy conditions as a weighted average of the ex-post real interest rate and the real exchange rate. We focus on the real ex-post interest rate for simplicity, but the results are not affected by the inclusion of the real exchange rate.

${ }^{26}$ Political polarization is defined as the maximum polarization between the executive party and the four principle parties of the legislature. The dummy is equal to 0 if the party has an absolute majority.

${ }^{27}$ The fiscal rule variable is defined as a dummy variable equal to 1 if the country has at least one of the following types of rules in place: an expenditure or revenue rule; a balanced budget rule; or a debt rule.
} 
political polarization increases the odd of a consolidation. Fiscal rules have a large impact on the likelihood of beginning a consolidation: having a fiscal rule increases the odds of beginning a consolidation by a factor of three.

Market pressure indicators do not appear to be associated with multiyear fiscal consolidations. The results of adding each category of market pressure are evaluated separately in columns (2) to (5) of Appendix II, Table 4. Column (6) includes all categories of market pressure simultaneously. Credit rating actions in the year before a consolidation positively affect the likelihood of a consolidation but are not statistically significant. Similarly, pressure in the longterm bond market does not appear to affect significantly the likelihood of beginning a multiyear consolidation. The estimated odds ratio is also counter-intuitively below 1 suggesting that the odds of beginning a consolidation are lower than the odds of non-consolidation. ${ }^{28}$ In contrast, pressure in short-term interest rates is positively associated with beginning a multiyear consolidation in the next year, but remains statistically insignificant. Pressure in the foreign exchange market also appears to be insignificant. Including all indicators in the regression does not materially change the magnitude of the estimated coefficients or their significance. Finally, we show that excluding the global financial crisis does not affect the significance of the market pressure indicators, except in the case of the long-term bond market (see last column).

\section{B. Robustness Checks}

In this section we present robustness checks of the baseline empirical results presented in the previous section. The robustness checks support the general finding that market pressure does not appear to be a key element preceding or associated with multiyear fiscal consolidations:

- $\quad$ Alternative indicators of market pressure. We examined other indicators of market pressure, including sovereign spreads ${ }^{29}$ the nominal effective exchange rate (NEER), and the equally-weighted sum of the change in the NEER minus the change in foreign reserves consistent with the literature on the Exchange Rate Market Pressure Index (EMP) popularized by Girton and Roper's (1977) seminal paper (Appendix II, Table 5). The four indicators demonstrate a positive correlation with the start of a consolidation but are not statistically significant.

\footnotetext{
${ }^{28}$ One potential explanation for this result is that the coefficient exhibits a downward bias since the emergence of market pressure in the year before a consolidation is conditional on the initial macro-fiscal condition, such as the debt level. We will explicitly test the interaction between market pressure and fiscal condition in the next section.

${ }^{29}$ We measure sovereign spreads as the difference between the long-term rate of country $i$ and the long-term rate of either the U.S. or Germany, and obtained similar results. To avoid dropping Germany and the U.S. from the sample, we use Germany as the benchmark for the U.S. and vice versa.
} 
- Sensitivity to thresholds. We analyzed the sensitivity of the results to the threshold values used in the identification of market pressure episodes (Box 1). The results reported in Appendix II, Table 6 suggest that baseline findings are not highly sensitive to the method of identifying market pressure. For instance, we find that only two of eight market pressure indicators - the sovereign spread between long-term interest rates and the NEER - become weakly significant when using a high threshold (from 75 to the 90 percentile) to identify large cross-sectional changes. ${ }^{30}$

- $\quad$ Sensitivity of measurement. We addressed the possibility that the method of measuring the market pressure indicators results in an incorrect identification. As the regression incorporates annual data, the baseline approach of measuring market pressure is based on the occurrence of large monthly changes in interest rates or currencies during the preceding year. We replaced these indicators with the average values of the financial variables observed in the previous 12 months. The results continue to suggest a lack of significant correlation between the level of financial variables in the previous year and the decision to consolidate. ${ }^{31}$

- $\quad$ Non-linearities. We explored the interaction between indices of market pressure and fiscal fundamentals. In particular, we included interaction terms between the measures of market pressure with the primary balance, the debt-to-GDP ratio, and the debt-stabilizing primary balance. None of the interaction effects are significant. In Appendix II, Table 7 we report the results of the interaction between the market pressure indicators and the debt-to- GDP ratio. ${ }^{32}$ The results in column (2) confirm that the impact of market pressure conditional on high debt level is positive, though the result is not significant.

- Sub-sample analysis. We re-estimated the baseline model in column 1 of Appendix II, Table 4 by eliminating one country at a time to cross-validate the results. Appendix II, Table 8 does not highlight materially different results from the baseline model reported in Appendix II, Table $4 .^{33}$

- Definition of dependent variable. We redefined the dependent variable of the baseline specification in column 1 of Appendix II, Table 4 from the probability of beginning a multiyear consolidation to the probability of being in a multiyear consolidation. In this

\footnotetext{
${ }^{30}$ We have also tried to change the definition by using a longer moving average for the calculation of the z-score equivalent to 60 months. Results are similar to those in Appendix II, Table 6 and are therefore unreported.

${ }^{31}$ The results are not reported but are available upon request.

${ }^{32}$ The results with the other fiscal indicators are not reported but are available upon request.

${ }^{33}$ Due to lack of space we report results only for eleven countries. The results for the other countries are though similar.
} 
way, the revised dependent variable is a dummy indicator equal to 1 if the country is in a multiyear consolidation. The only significant result we find is that a credit rating downgrade in the previous year is about four times more likely to lead to a multiyear consolidation phase (Appendix II, Table 9). However, the different specification of the dependent variable also strengthens the importance of fiscal rules.

Overall, the finding that market pressure has not been the main feature associated with discretionary decisions to begin multiyear fiscal consolidations appears to be robust to different specifications and variable choices. We interpret the regression results as supporting the stylized facts presented in Section V. While market pressure has played a major role in specific fiscal adjustment episodes, it does not seem to be a pervasive phenomenon associated with multiyear fiscal consolidations programs.

\section{Policy IMPLications}

Market pressure appears to have been an important factor in a number of multiyear fiscal consolidations, but was not the main 'trigger' of fiscal adjustments in OECD countries during 1980-2011..$^{34}$ The historical evidence suggests that most advanced countries with weak fundamentals pursued multiyear fiscal consolidations without the occurrence of market pressure. If history is a guide, the absence of market pressure will not inhibit fiscal consolidation in advanced economies with currently weak fundamentals, such as high debt ratios, adverse debt dynamics or below trend growth. However, there are also important differences between the current macroeconomic and fiscal environment compared to the last 30 years. These differences include a deeper recession and shallower recovery than previous post-war recessions, increased policy uncertainty, monetary union in the euro area, and unprecedented monetary accommodation.

Expected monetary policy responses can also influence fiscal adjustment plans, including the size and pace of intended fiscal adjustments. The evidence presented in this paper includes periods when countries had greater monetary flexibility compared to the current situation, which allowed for the possibility that fiscal consolidations could be more readily accommodated by monetary policy. In this context, lessons from history are useful but should be interpreted with caution.

\footnotetext{
${ }^{34}$ Market pressure may still play an indirect role if policymakers consolidate public finances owing to concerns of potential market pressure or an inability to roll over future gross financing requirements.
} 


\section{CONCLUSION}

This paper has investigated the association between market pressure and discretionary multiyear fiscal consolidations in OECD countries during the last three decades. In the stylized conceptual framework outlined in Section II, market pressure through higher interest rates implies the need for fiscal adjustment. This model motivated our empirical work to establish the stylized facts on this potential link. We find that market pressure has not been a crucial element for undertaking multiyear fiscal consolidations as only about a third (34 percent) of the identified multiyear consolidations are associated with market pressure. Regression results further support the descriptive statistical finding that market pressure has not been a pervasive phenomenon associated with multiyear fiscal adjustment programs to reduce high budget deficits. While market pressure was not a pervasive feature of observed multiyear fiscal consolidations, the median adjustment under market pressure was significantly larger than other adjustments not taken under market pressure.

In contrast to market pressure, virtually all multiyear adjustments designed to reduce high budget deficits were associated with initially weak macroeconomic and fiscal fundamentals, such as adverse debt dynamics, high debt levels, and below trend growth. Based on individual indicators, the "incidence" of weak fundamentals on multiyear consolidations plans ranges from 68 percent for negative output gaps to 86 percent for high debt levels. Almost three quarters of multiyear consolidation programs are associated with multiple sources of weak macro fiscal fundamentals (i.e., 39 out of 53 episodes).

We interpret the evidence that most fiscal consolidations during the last three decades have proceeded without market pressure, as highlighting the role of other elements, such as convergence within the euro monetary union or efforts to act prudently by undertaking a needed fiscal adjustment to avoid prospective market pressure. 


\section{REFERENCES}

Ağca, Senay, and Deniz Igan, 2013, "Fiscal Consolidation and the Cost of Credit: Evidence from Syndicated Loans," IMF Working Paper 13/36 (Washington: International Monetary Fund).

Alesina, Alberto and Silvia Ardagna, 1998, "Tales of Fiscal Adjustment," Economic Policy (October), pp. 498-545. , and Silvia, Ardagna, 2009, "Large Changes in Fiscal Policy: Taxes Versus Spending," National Bureau of Economic Research (NBER), Working Paper No 15438.

, 2010, "Fiscal Adjustments: Lessons from Recent History," Prepared for the Ecofin Meeting in Madrid, April 15.

Ardagna, Silvia, 2009, "Financial Markets' Behavior around Episodes of Large Changes in the Fiscal Stance," European Economic Review, Vol. 53, (January), pp. 37-55.

Bergman Michael, Michael M. Hutchison, Svend E. Hougaard Jensen, 2013, "Do Sound Public Finances Require Fiscal Rules or is Market Pressure Enough?" European Economy, Economic Papers, No. 489, Brussels.

Blanchard, Olivier, and Roberto Perotti, 2002, "An Empirical Characterization of the Dynamic Effects of Changes in Government Spending and Taxes on Output," The Quarterly Journal of Economics, MIT Press, Vol. 117(4), (November), pp. 13291368.

Debrun, Xavier, and Tidiane Kinda, 2013, "That Squeezing Feeling: The Interest Burden and Public Debt Stabilization," IMF Working Paper No. 13/125 (Washington: International Monetary Fund).

Devries, Pete, Jaime Guajardo, Daniel Leigh and Andrea Pescatori, 2011, “A New Action Based Dataset of Fiscal Consolidation," IMF Working Paper 11/128 (Washington: International Monetary Fund).

De Groot, Oliver, Federic Holm-Hadulla, and Nadine Leiner-Killinger, 2012, "Cost of Borrowing Shocks and Fiscal Adjustment," December, ECB Working Paper No. 1503 (Frankfurt: European Central Bank).

European Commission, 2007, "European Economy—Public Finances in EMU," European Commission, Brussels. 
Girton, Lance, and Don Roper, 1977, "A Monetary Model of Exchange Market Pressure Applied to the Postwar Canadian Experience," American Economic Review, Vol. 67 (September), pp. 537-548.

Guichard, Stéphanie, Mike Kennedy, Eckhard Wurzel, and Christophe André, 2007, "What Promotes Fiscal Consolidation: OECD Country Experiences," OECD Economics Department Working Papers 553 (Paris: Organisation for Economic Co-Operation and Development).

International Monetary Fund, 2013, Fiscal Monitor, April 2013: Fiscal Adjustment in an Uncertain World (Washington). Available at:

(http://www.imf.org/external/pubs/ft/fm/2013/01/fmindex.htm).

Mauro, Paolo, Rafael Romeu, Ariel Binder, and Asad Zaman, 2013, "A Modern History of Fiscal Prudence and Profligacy," IMF Working Paper No. 13/5 (Washington: International Monetary Fund).

Molnar, Margit, 2012, "Fiscal Consolidation: Part 5, What Factors Determine the Success of Consolidation Efforts?" OECD Economics Department Working Papers No. 936 (Paris: Organisation for Economic Co-Operation and Development).

Perotti, Roberto, 2012, "The Austerity Myth: Gain Without Pain," in Fiscal Policy after the Financial Crisis," eds. Alberto Alesina and Francesco Giavazzi, NBER (Cambridge, Massachusetts: National Bureau of Economic Research).

Riera-Crichton, D., C. Vegh, and G. Vuletin, 2012, "Tax Multipliers: Pitfalls in Measurement and Identification,” NBER Working Paper No. 18497 (Cambridge, Massachusetts: National Bureau of Economic Research).

Romer, Christina D., and David H. Romer, 2010, "The Macroeconomic Effects of Tax Changes: Estimates Based on a New Measure of Fiscal Shocks," American Economic Review, Vol. 100 (June), pp. 763-801.

Jeffrey Sachs, and Daniel Cohen, 1982, "LDC Borrowing with Default Risk,” NBER Working Papers No. 0925 (Cambridge, Massachusetts: National Bureau of Economic Research).

Vegh, Carlos "Open Economy Macroeconomics in Developing Countries," forthcoming (to be published by MIT Press). Available at http://econweb.umd.edu/ vegh/book/book.htm

Von Hagen, Jurgen, Rolf R. Strauch, 2001, "Fiscal Consolidations: Quality, Economic Conditions, and Success," Public Choice, Springer, Vol. 109, (December), pp. 327-46. 


\section{APPENDIX I. IDENTIFICATION OF FISCAL CONSOLIDATION EPISODES}

The primary data source on episodes of fiscal consolidation is Devries et al. (2011). On the basis of the narrative method, the authors identified annual episodes of discretionary fiscal consolidation that were motivated by the intention to reduce high budget deficits rather than cyclical fluctuations in the fiscal balance. The authors identified 173 annual episodes of discretionary fiscal consolidation across 17 OECD countries during the 1978 to 2009 period.

Many annual consolidation episodes in the dataset of Devries et al. (2011) are part of multiyear consolidation programs. A multiyear consolidation episode consisting of at least two years is identified in this paper as satisfying at least one of the following two criteria:

- We refer to Devries et al. (2011) to check when a new multiyear fiscal consolidation was implemented based on their narrative evidence; and

- When the government in charge announces a change in the previous consolidation plan. When this evidence is unavailable in the narrative evidence, we take a change in government as a proxy.

The application of these identifying criteria is outlined in the illustrative country examples below:

- $\quad$ Australia. According to Devries et al. (2011), Australia was undergoing a discretionary consolidation between 1994 and 1999 (Appendix I, Table 1). However, in 1996 a new coalition government announced a new multiyear fiscal consolidation plan. Therefore, we code 1996 as the starting year of a new episode.

- Germany. In other cases, even if the government changes, the new government continues fiscal consolidation plans initiated by previous governments. The new German government in 1999 continued the fiscal consolidation plan started by the previous government. Hence, it does not lead to a new multiyear consolidation plan in our dataset.

- Canada. In cases where a change in policy is not evident in the narrative dataset, such as Canada, we take a change in government as the year of the initiation of a new multiyear consolidation program. ${ }^{35}$

In terms of timing, we focus on the fiscal year, as opposed to the calendar year, in order to identify appropriately the relevant discretionary fiscal policy changes for the following year.

\footnotetext{
${ }^{35}$ Given this uncertainty over identification of the episode for Canada, we also run the regressions excluding Canada from the sample. The results are robust to this exclusion.
} 
In this way, we capture the relevant relationship between market pressure and fiscal policy changes.

\section{Figure 1. Timing of Fiscal Consolidation and Market Pressure Episodes 1/}

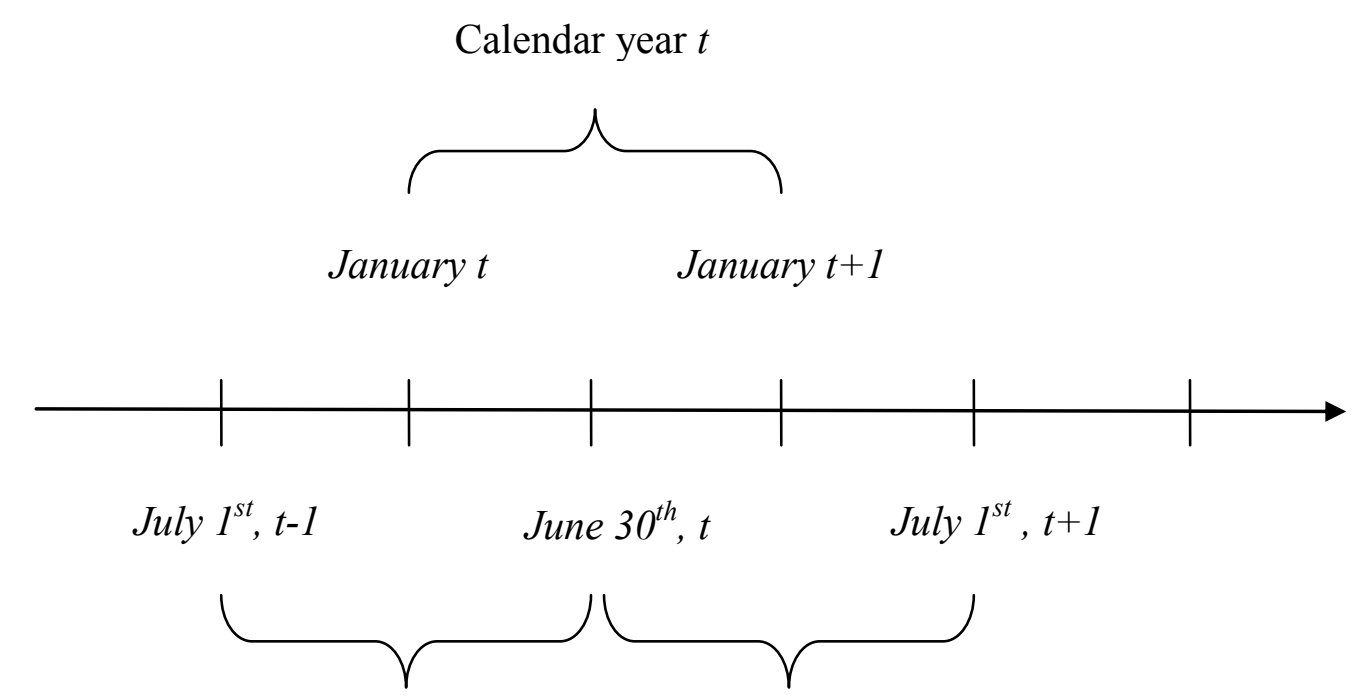

Fiscal year $t-1$

Fiscal year $t$

1/ Note: The chart explains our convention for the timing of consolidation episodes and market pressure. We code a fiscal consolidation in year $t$ as associated to the fiscal year which spans July 1 in year $t$ to June 30 in year $t+1$. Episodes of market pressure which occurs between July 1 in year $t$ to June 30 in year $t+1$ are contemporaneous to the fiscal episode, while those occurring between July 1 in year $t-1$ to June 30 in year $t$ are coded as preceding the consolidation episode in year $t$. 
APPENDIX I, Table 1. Planned Multiyear Consolidation Episodes Based on the Narrative Approach, 1980-2011 1/

(in percent of GDP)

\begin{tabular}{|c|c|c|c|c|c|c|c|c|c|c|c|c|c|c|c|c|c|c|c|c|c|c|c|c|c|c|c|c|c|c|c|c|c|c|}
\hline & 1978 & 1979 & 1980 & 1981 & 1982 & 1983 & 1984 & 1985 & 1986 & 1987 & 1988 & 1989 & 1990 & 1991 & 1992 & 1993 & 1994 & 1995 & 1996 & 1997 & 1998 & 1999 & 2000 & 2001 & 2002 & 2003 & 2004 & 2005 & 2006 & 2007 & 2008 & 2009 & 2010 & 2011 \\
\hline AUS & & & & & & & & 0.45 & 1.02 & 0.90 & 0.10 & & & & & & 0.25 & 0.50 & 0.62 & 0.70 & 0.37 & \begin{tabular}{l|l|}
0.04 \\
\end{tabular} & & & & & & & & & & & & \\
\hline AUT & & & 0.80 & 1.56 & & & 2.04 & & & & & & & & & & & & 2.41 & 1.56 & & & & 1.02 & 0.55 & & & & & & & & & 0.88 \\
\hline BEL & & & & & 1.66 & 1.79 & 0.69 & 1.61 & & 2.80 & & & 0.60 & & 1.79 & 0.92 & 1.15 & & 1.00 & $\begin{array}{l}0.91 \\
\end{array}$ & & & & & & & & & & & & & 0.62 & 0.94 \\
\hline CAN & & & & & & & 0.27 & 1.03 & 0.99 & 0.28 & 0.30 & 0.31 & 0.86 & 0.40 & 0.21 & 0.35 & 0.49 & 0.99 & 0.97 & 0.47 & & & & & & & & & & & & & & 0.10 \\
\hline DEU & & & & & 1.18 & 0.87 & 0.18 & & & & & & & 1.11 & 0.46 & 0.11 & 0.91 & 1.08 & & 1.60 & -0.10 & 0.30 & 0.70 & & & 0.74 & 0.40 & & 0.50 & 0.90 & & & & 0.50 \\
\hline DNK & & & & & & 2.77 & 2.38 & 1.54 & -0.72 & & & & & & & & & 0.30 & & & & & & & & & & & & & & & & 0.50 \\
\hline ESP & & & & & & 1.90 & 1.12 & & & & & 1.22 & -0.40 & & 0.70 & \begin{tabular}{l|l|}
1.10 \\
\end{tabular} & 1.60 & 0.74 & 1.30 & 1.20 & & & & & & & & & & & & & 2.70 & 2.20 \\
\hline FIN & & & & & & & & & & & & & & & 0.91 & 3.71 & 3.46 & 1.65 & 1.47 & 0.23 & & & & & & & & & & & & & 0.23 & 0.94 \\
\hline FRA & & 0.85 & & & & & & & & 0.26 & & -0.20 & & 0.25 & -0.10 & & & 0.28 & 1.33 & 0.50 & & $-0.10-$ & -0.20 & & & & & & & & & & & 2.31 \\
\hline GBR & & 0.27 & 0.08 & 1.58 & 0.53 & & & & & & & & & & & & 0.83 & 0.28 & \begin{tabular}{l|l|}
0.30 \\
\end{tabular} & 0.69 & 0.31 & 0.21 & & & & & & & & & & & 0.60 & 1.90 \\
\hline IRL & & & & & 2.80 & 2.50 & 0.29 & 0.12 & \begin{tabular}{l|l|}
0.74 \\
\end{tabular} & 1.65 & 1.95 & & & & & & & & & & & & & & & & & & & & & 4.74 & 2.60 & 3.70 \\
\hline ITA & & & & & & & & & & & & & & 2.77 & 3.50 & \begin{tabular}{|l|l|}
4.49 \\
\end{tabular} & 1.43 & \begin{tabular}{l|l|}
4.20 \\
\end{tabular} & 0.34 & 1.82 & 0.68 & & & & & & 1.30 & 1.00 & 1.39 & 1.03 & & & & 0.78 \\
\hline JPN & & 0.12 & 0.21 & 0.43 & 0.71 & 0.42 & & & & & & & & & & & & & & 1.43 & 0.48 & & & & & 0.48 & 0.64 & 0.28 & 0.72 & 0.15 & & & & \\
\hline NLD & & & & 1.75 & 1.71 & 3.24 & 1.76 & 1.24 & \begin{tabular}{l|l|}
1.74 \\
\end{tabular} & 1.48 & 0.06 & & & 0.87 & 0.74 & 0.12 & & & & & & & & & & & \begin{tabular}{|l|}
1.70 \\
\end{tabular} & \begin{tabular}{l|l}
0.50 \\
\end{tabular} & & & & & & 0.34 \\
\hline PRT & & & & & & 2.30 & & & & & & & & & & & & & & & & & 0.50 & & 1.60 & -0.75 & & \begin{tabular}{|l|l|}
0.60 \\
\end{tabular} & 1.65 & 1.40 & & & 2.26 & 3.05 \\
\hline SWE & & & & & & & 0.90 & & & & & & & & & 1.81 & \begin{tabular}{l|l}
0.78 \\
\end{tabular} & 3.50 & 2.00 & 1.50 & 1.00 & & & & & & & & & & & & 0.10 & 0.40 \\
\hline JSA & 0.14 & & 0.06 & 0.23 & & & & 0.21 & 0.10 & & 0.85 & & 0.33 & 0.58 & 0.52 & 0.32 & 0.90 & 0.53 & 0.29 & 0.30 & 0.15 & & & & & & & & & & & & & \\
\hline
\end{tabular}

1/ Discretionary consolidations are based on action-based or planned measures to undertake a fiscal adjustment to reduce a high budget deficit. Multiyear episodes are highlighted in yellow with a box. For example, there are three multiyear consolidation episodes for Canada during the continuous 1984 to 1997 period of annual consolidations. There are 53 discrete multiyear consolidation episodes. 


\section{APPENDIX I, Table 2. Large Multiyear Consolidation Episodes Based on the "CAPB" Approach, 1980-2011 1/}

(in percent of GDP)

\begin{tabular}{|c|c|c|c|c|c|c|c|c|c|c|c|c|c|c|c|c|c|c|c|c|c|c|c|c|c|c|c|c|c|c|}
\hline & 1978 & 1979 & 1980 & 1981 & 1982 & 1983 & 1984 & 1985 & 1986 & 1987 & 1988 & 1989 & 1990 & 1991 & 1992 & 1993 & 1994 & 1995 & 1996 & 1997 & 1998 & 1999 & 2000 & 2001 & 2002 & 2003 & 2004 & 2005 & 20062 & 2007 \\
\hline AUS & & & & & & & & & & 1.71 & 1.60 & & & & & & & & & & & & & & & & & & & \\
\hline AUT & & & & & & & 2.02 & & & & & & & & & & & & 2.29 & 2.83 & & & & & & & & 2.92 & & \\
\hline BEL & & & & & 4.31 & & 4.69 & & & 1.61 & & & & & & & & & & & & & & & & & & & 2.70 & \\
\hline CAN & & & & 2.13 & & & & & 2.14 & 1.74 & & & & & & & & 1.58 & 2.20 & 2.25 & & & & & & & & & & \\
\hline DEU & & & & & & & & & & & & & & & & & & & 6.79 & & & & 2.42 & & & & & & & \\
\hline DNK & & & & & & 4.37 & 5.17 & 1.76 & 3.64 & & & & & & & & & & & & & & & & & & & 2.46 & & \\
\hline ESP & & & & & & & & & 1.65 & 2.88 & & & & & & & 1.88 & & 1.66 & & & & & & & & & & & \\
\hline FIN & & & & 1.50 & & & 1.60 & & & & 3.34 & & & & & & 3.23 & & 2.54 & & 1.78 & & 4.07 & & & & & & & \\
\hline FRA & & 1.56 & & & & & & & & & & & & & & & & & 1.66 & & & & & & & & & & & \\
\hline GBR & & & & & 2.03 & & & & & & 1.66 & & & & & & & & 1.56 & 1.99 & 1.96 & & 2.51 & & & & & & & \\
\hline IRL & & & & & & & 1.99 & & & 2.09 & 3.54 & 1.87 & & & & & & & & & & & 1.69 & & & & & & & \\
\hline ITA & & & 1.62 & & 2.11 & & & & & & & & 1.52 & 1.64 & 1.65 & & & & & 2.16 & & & & & & & & & & 2.53 \\
\hline JPN & & & & & & & 1.91 & & & & & & & & & & & & & & & 5.09 & & 1.96 & & & & & 4.44 & \\
\hline NLD & & & & & & 2.24 & & & & & 1.73 & & & 2.31 & & 1.95 & & & 7.03 & & & & & & & & & & & \\
\hline PRT & & & & & 1.55 & 2.39 & & & 2.35 & & 1.92 & & & & 1.81 & & & 1.51 & & & & & & & 1.64 & & & & 2.09 & \\
\hline SWE & & & & 2.07 & & 1.51 & 2.30 & & 2.37 & 2.93 & & & & & & & 3.61 & & 4.82 & 2.18 & & & & & & & 1.92 & & & \\
\hline USA & & & & & & & & & & & & & & & & & & & & & & & & & & & & & & \\
\hline
\end{tabular}

Source: Alesina and Ardagna, 2010.

$1 /$ Discretionary consolidations are identified as changes in the cyclically-adjusted primary balance (CAPB) of at least 1.5 percent of GDP in any year as reported by Alesina and Ardagna, 2010. This approach focuses on large annual changes in discretionary fiscal policy and does not aim to identify multiyear episodes directly. There are 13 instances of consecutive annual episodes with changes in the CAPB exceeding 1.5 percent of GDP. 
APPENDIX II. REGRESSION ANALYSIS

Appendix II, Table 3. Summary Statistics

\begin{tabular}{lrrrr}
\hline & Mean & Min & Max & SD \\
\hline \hline Primary Balance & -0.5 & -28.5 & 9.0 & 3.6 \\
Debt-Stabilizing Primary Balance & -0.6 & -15.9 & 11.7 & 2.6 \\
Debt to GDP & 67.5 & 13.3 & 192.7 & 29.8 \\
Output Gap & -0.1 & -10.1 & 9.8 & 2.8 \\
Current Account to GDP & -0.3 & -14.6 & 9.3 & 3.8 \\
Short-Term Real Rate & 3.3 & -3.4 & 12.3 & 2.8 \\
Election & 0.3 & 0.0 & 1.0 & 0.5 \\
Years Left in current Term & 1.7 & 0.0 & 4.0 & 1.3 \\
Polarization & 0.7 & 0.0 & 1.0 & 0.5 \\
Fiscal Rule & 0.6 & 0.0 & 1.0 & 0.5 \\
LT Bond pressure & 0.2 & 0.0 & 1.0 & 0.4 \\
ST Bond Pressure & 0.3 & 0.0 & 1.0 & 0.4 \\
FXPressure & 0.1 & 0.0 & 1.0 & 0.3 \\
Rating Pressure & 0.1 & 0.0 & 1.0 & 0.3 \\
LT Spread Pressure & 0.1 & 0.0 & 1.0 & 0.3 \\
ST Spread Pressure & 0.1 & 0.0 & 1.0 & 0.3 \\
NEER Pressure & 0.1 & 0.0 & 1.0 & 0.3 \\
EMP & 0.1 & 0.0 & 1.0 & 0.3 \\
\hline
\end{tabular}

Note: See Data Appendix for variables source and definitions. 


\section{Appendix II, Table 4. Regression Results of a Conditional Logit Panel Regression Model 1/}

(coefficients are expressed as "odds ratios" or the probability of beginning a multiyear consolidation divided by the probability of no consolidation; robust z-statistics in parentheses)

\begin{tabular}{|c|c|c|c|c|c|c|}
\hline VARIABLES & $\begin{array}{c}(1) \\
\text { Baseline } \\
\end{array}$ & $\begin{array}{c}(2) \\
\text { Credit Rating } \\
\end{array}$ & $\begin{array}{c}(3) \\
\text { LT Bond Market }\end{array}$ & $\begin{array}{c}(4) \\
\text { ST Bond Market }\end{array}$ & $\begin{array}{c}(5) \\
\text { US Dollar }\end{array}$ & $\begin{array}{c}(6) \\
\text { All indices }\end{array}$ \\
\hline \multicolumn{7}{|l|}{ Fiscal Fundamentals } \\
\hline Primary Balance to GDP & $\begin{array}{l}0.74^{\star \star *} \\
(-3.376)\end{array}$ & $\begin{array}{l}0.74^{* * *} \\
(-3.416)\end{array}$ & $\begin{array}{l}0.74^{* * *} \\
(-3.341)\end{array}$ & $\begin{array}{l}0.74^{* * *} \\
(-3.386)\end{array}$ & $\begin{array}{l}0.74^{* * *} \\
(-3.618)\end{array}$ & $\begin{array}{l}0.73^{* * *} \\
(-3.617)\end{array}$ \\
\hline Debt-Stabilizing Primary Balance & $\begin{array}{l}1.24^{\star \star \star} \\
(2.793)\end{array}$ & $\begin{array}{l}1.24^{\star \star \star} \\
(2.883)\end{array}$ & $\begin{array}{l}1.26^{\star \star} \\
(2.515)\end{array}$ & $\begin{array}{l}1.25^{\star \star \star} \\
(3.036)\end{array}$ & $\begin{array}{l}1.27^{\star \star \star} \\
(2.829)\end{array}$ & $\begin{array}{l}1.29^{* \star *} \\
(2.906)\end{array}$ \\
\hline Debt to GDP & $\begin{array}{c}0.99 \\
(-0.480)\end{array}$ & $\begin{array}{c}0.99 \\
(-0.508)\end{array}$ & $\begin{array}{c}0.99 \\
(-0.453)\end{array}$ & $\begin{array}{c}0.99 \\
(-0.506)\end{array}$ & $\begin{array}{c}0.99 \\
(-0.493)\end{array}$ & $\begin{array}{c}0.99 \\
(-0.519)\end{array}$ \\
\hline \multicolumn{7}{|l|}{ Macro Fundamentals } \\
\hline Output Gap & $\begin{array}{c}1.12 \\
(1.241)\end{array}$ & $\begin{array}{c}1.12 \\
(1.187)\end{array}$ & $\begin{array}{c}1.13 \\
(1.273)\end{array}$ & $\begin{array}{c}1.13 \\
(1.305)\end{array}$ & $\begin{array}{c}1.14 \\
(1.347)\end{array}$ & $\begin{array}{c}1.15 \\
(1.454)\end{array}$ \\
\hline Current Account to GDP & $\begin{array}{c}0.94 \\
(-0.832)\end{array}$ & $\begin{array}{c}0.94 \\
(-0.800)\end{array}$ & $\begin{array}{c}0.94 \\
(-0.794)\end{array}$ & $\begin{array}{c}0.95 \\
(-0.707)\end{array}$ & $\begin{array}{c}0.93 \\
(-0.959)\end{array}$ & $\begin{array}{c}0.95 \\
(-0.736)\end{array}$ \\
\hline Short-Term Real Rate & $\begin{array}{c}0.98 \\
(-0.198)\end{array}$ & $\begin{array}{c}0.98 \\
(-0.185)\end{array}$ & $\begin{array}{c}0.97 \\
(-0.262)\end{array}$ & $\begin{array}{c}0.98 \\
(-0.237)\end{array}$ & $\begin{array}{c}0.99 \\
(-0.069)\end{array}$ & $\begin{array}{c}0.98 \\
(-0.181)\end{array}$ \\
\hline \multicolumn{7}{|l|}{ Political-Institutional Variables } \\
\hline Post Elections & $\begin{array}{l}4.49^{\star * \star} \\
(2.736)\end{array}$ & $\begin{array}{l}4.49^{* * *} \\
(2.686)\end{array}$ & $\begin{array}{l}4.40^{\star \star *} \\
(2.727)\end{array}$ & $\begin{array}{l}4.40^{* * *} \\
(2.607)\end{array}$ & $\begin{array}{l}4.62^{\star \star \star} \\
(2.728)\end{array}$ & $\begin{array}{l}4.46^{\star \star *} \\
(2.605)\end{array}$ \\
\hline Years Left in Current Term & $\begin{array}{l}1.65^{*} \\
(1.860)\end{array}$ & $\begin{array}{l}1.65^{*} \\
(1.873)\end{array}$ & $\begin{array}{l}1.64^{*} \\
(1.866)\end{array}$ & $\begin{array}{l}1.64^{*} \\
(1.807)\end{array}$ & $\begin{array}{l}1.65^{\star} \\
(1.905)\end{array}$ & $\begin{array}{l}1.63^{*} \\
(1.850)\end{array}$ \\
\hline Political Polarization & $\begin{array}{c}0.59 \\
(-0.970)\end{array}$ & $\begin{array}{c}0.59 \\
(-1.010)\end{array}$ & $\begin{array}{c}0.59 \\
(-0.914)\end{array}$ & $\begin{array}{c}0.58 \\
(-0.999)\end{array}$ & $\begin{array}{c}0.64 \\
(-0.850)\end{array}$ & $\begin{array}{c}0.62 \\
(-0.863)\end{array}$ \\
\hline Fiscal Rule & $\begin{array}{l}3.20^{*} \\
(1.662)\end{array}$ & $\begin{array}{l}3.20^{*} \\
(1.677)\end{array}$ & $\begin{array}{c}3.17 \\
(1.584)\end{array}$ & $\begin{array}{l}3.16^{*} \\
(1.681)\end{array}$ & $\begin{array}{c}3.01 \\
(1.638)\end{array}$ & $\begin{array}{l}2.93 \\
(1.598)\end{array}$ \\
\hline \multicolumn{7}{|l|}{ Indicators of Market Pressure } \\
\hline Rating Pressure & & $\begin{array}{c}1.00 \\
(-0.006)\end{array}$ & & & & $\begin{array}{c}0.95 \\
(-0.078)\end{array}$ \\
\hline Long-Term Bond Pressure & & & $\begin{array}{c}0.44 \\
(-1.190)\end{array}$ & & & $\begin{array}{c}0.44 \\
(-1.220)\end{array}$ \\
\hline Short-Term bond Pressure & & & & $\begin{array}{c}1.19 \\
(0.447)\end{array}$ & & $\begin{array}{c}1.36 \\
(0.788)\end{array}$ \\
\hline US $\$$ rate & & & & & $\begin{array}{c}0.54 \\
(-1.379)\end{array}$ & $\begin{array}{c}0.54 \\
(-1.416)\end{array}$ \\
\hline Observations & 450 & 450 & 450 & 450 & 450 & 450 \\
\hline R2 & 0.323 & 0.323 & 0.329 & 0.323 & 0.326 & 0.334 \\
\hline AIC & 236.7 & 238.7 & 237.3 & 238.6 & 237.9 & 242.2 \\
\hline Number of id & 17 & 17 & 17 & 17 & 17 & 17 \\
\hline
\end{tabular}

1/ Odds ratios express the likelihood of undertaking a multiyear consolidation divided by the probability of not starting a consolidation. For example, an additional year in a government's mandate (i.e., "Years left in Current Term") increases the odds of a multiyear consolidation by 65 percent (column 1). In contrast, a higher primary balance ratio decreases the odds of a consolidation by about 36 percent (column 1). The coefficients are best treated as a means of quantifying the relative importance of variables. ${ }^{* *} p<0.01,{ }^{* *} p<0.05,{ }^{*} p<0.1$ 


\section{Appendix II, Table 5. Different Indicators of Market Pressure 1/}

\begin{tabular}{|c|c|c|c|c|}
\hline VARIABLES & $\begin{array}{c}\text { (1) } \\
\text { LT Spread }\end{array}$ & $\begin{array}{c}(2) \\
\text { ST Spread }\end{array}$ & $\begin{array}{c}(3) \\
\text { NEER }\end{array}$ & $\begin{array}{c}(4) \\
\text { EMP }\end{array}$ \\
\hline \multicolumn{5}{|l|}{ Fiscal Fundamentals } \\
\hline Primary Balance to GDP & $\begin{array}{l}0.75^{\star \star \star} \\
(-3.260)\end{array}$ & $\begin{array}{l}0.75^{\star * *} \\
(-3.432)\end{array}$ & $\begin{array}{l}0.74^{* * *} \\
(-3.439)\end{array}$ & $\begin{array}{l}0.74^{* * *} \\
(-3.406)\end{array}$ \\
\hline Debt-Stabilizing Primary Balance & $\begin{array}{l}1.23^{\star \star \star} \\
(2.788)\end{array}$ & $\begin{array}{l}1.24^{* * \star} \\
(2.728)\end{array}$ & $\begin{array}{l}1.24^{\star * *} \\
(2.637)\end{array}$ & $\begin{array}{l}1.23^{* \star *} \\
(2.769)\end{array}$ \\
\hline Debt to GDP & $\begin{array}{c}0.99 \\
(-0.441)\end{array}$ & $\begin{array}{c}0.99 \\
(-0.455)\end{array}$ & $\begin{array}{c}1.00 \\
(-0.313)\end{array}$ & $\begin{array}{c}1.00 \\
(-0.394)\end{array}$ \\
\hline \multicolumn{5}{|l|}{ Macro Fundamentals } \\
\hline Output Gap & $\begin{array}{c}1.11 \\
(1.122)\end{array}$ & $\begin{array}{c}1.12 \\
(1.251)\end{array}$ & $\begin{array}{c}1.14 \\
(1.338)\end{array}$ & $\begin{array}{c}1.14 \\
(1.307)\end{array}$ \\
\hline Current Account to GDP & $\begin{array}{c}0.94 \\
(-0.773)\end{array}$ & $\begin{array}{c}0.94 \\
(-0.755)\end{array}$ & $\begin{array}{c}0.94 \\
(-0.814)\end{array}$ & $\begin{array}{c}0.95 \\
(-0.614)\end{array}$ \\
\hline Short-Term Real Rate & $\begin{array}{c}0.98 \\
(-0.177)\end{array}$ & $\begin{array}{c}0.99 \\
(-0.154)\end{array}$ & $\begin{array}{c}0.96 \\
(-0.466)\end{array}$ & $\begin{array}{c}0.98 \\
(-0.168)\end{array}$ \\
\hline \multicolumn{5}{|l|}{ Political-Institutional Variables } \\
\hline Post Elections & $\begin{array}{l}4.53^{* * *} \\
(2.785)\end{array}$ & $\begin{array}{l}4.40^{\star \star \star *} \\
(2.626)\end{array}$ & $\begin{array}{l}4.20^{\star * *} \\
(2.773)\end{array}$ & $\begin{array}{l}4.75^{\star * *} \\
(2.704)\end{array}$ \\
\hline Years Left in Current Term & $\begin{array}{c}1.64^{*} \\
(1.785)\end{array}$ & $\begin{array}{l}1.64^{*} \\
(1.835)\end{array}$ & $\begin{array}{c}1.59^{*} \\
(1.750)\end{array}$ & $\begin{array}{c}1.69^{*} \\
(1.898)\end{array}$ \\
\hline Political Polarization & $\begin{array}{c}0.56 \\
(-1.070)\end{array}$ & $\begin{array}{c}0.57 \\
(-0.991)\end{array}$ & $\begin{array}{c}0.58 \\
(-0.940)\end{array}$ & $\begin{array}{c}0.59 \\
(-0.923)\end{array}$ \\
\hline Fiscal Rule & $\begin{array}{c}3.37^{*} \\
(1.714)\end{array}$ & $\begin{array}{c}3.23^{*} \\
(1.704)\end{array}$ & $\begin{array}{c}3.18 \\
(1.601)\end{array}$ & $\begin{array}{c}3.14^{*} \\
(1.653)\end{array}$ \\
\hline \multicolumn{5}{|l|}{ Indicators of Market Pressure } \\
\hline Long-Term Sovereign Spread Pressure & $\begin{array}{c}1.72 \\
(1.331)\end{array}$ & & & \\
\hline Short-Term Sovereign Spread Pressure & & $\begin{array}{c}1.50 \\
(0.783)\end{array}$ & & \\
\hline NEER & & & $\begin{array}{c}1.65 \\
(1.340)\end{array}$ & \\
\hline EMP & & & & $\begin{array}{c}1.66 \\
(0.948)\end{array}$ \\
\hline Observations & 450 & 450 & 450 & 450 \\
\hline $\mathrm{R} 2$ & 0.326 & 0.325 & 0.326 & 0.327 \\
\hline AIC & 237.9 & 238.2 & 237.9 & 237.7 \\
\hline Number of id & 17 & 17 & 17 & 17 \\
\hline
\end{tabular}

1/ LT spread refers to the equation using the sovereign spread in the long-term bond market. ST spread refers to the equation using the sovereign spread in the short-term bond market. NEER refers to the equation using the Nominal Effective Exchange Rate. EMP refers to the equation using the Exchange Rate Market Pressure Index. ${ }^{* * *} p<0.01,{ }^{* *} p<0.05,{ }^{*} p<0.1$. 
Appendix, II, Table 6. Different Identification of Market Pressure Episodes 1/ (robust z-statistics in parentheses)

\begin{tabular}{|c|c|c|c|c|c|c|c|c|}
\hline VARIABLES & $\begin{array}{c}1) \\
\text { Credit Rating } \\
\end{array}$ & $\begin{array}{c}(2) \\
\text { LT Bond Market }\end{array}$ & $\begin{array}{c}(3) \\
\text { ST Bond Market } \\
\end{array}$ & $\begin{array}{c}(4) \\
\text { US Dollar } \\
\end{array}$ & $\begin{array}{c}(5) \\
\text { NEER } \\
\end{array}$ & $\begin{array}{c}6) \\
\text { EMP }\end{array}$ & $\begin{array}{c}(7) \\
\text { LT-Spread } \\
\end{array}$ & $\begin{array}{c}(8) \\
\text { ST-Spread }\end{array}$ \\
\hline \multicolumn{9}{|l|}{ Fiscal Fundamentals } \\
\hline Primary Balance to GDP & $\begin{array}{c}0.74^{\star \star *} \\
(-3.416)\end{array}$ & $\begin{array}{l}0.74^{* * *} \\
(-3.363)\end{array}$ & $\begin{array}{c}0.74^{* * *} \\
(-3.446)\end{array}$ & $\begin{array}{c}0.74^{* * *} \\
(-3.444)\end{array}$ & $\begin{array}{c}0.74^{\star * *} \\
(-3.463)\end{array}$ & $\begin{array}{c}0.73^{* * *} \\
(-3.400)\end{array}$ & $\begin{array}{l}0.75^{\star * *} \\
(-3.278)\end{array}$ & $\begin{array}{c}0.74^{\star \star *} \\
(-3.408)\end{array}$ \\
\hline Debt-Stabilizing Primary Balance & $\begin{array}{l}1.24^{\star \star \star} \\
(2.883)\end{array}$ & $\begin{array}{l}1.25^{\star \star} \\
(2.467)\end{array}$ & $\begin{array}{l}1.24^{\star \star \star} \\
(2.802)\end{array}$ & $\begin{array}{l}1.27^{\star \star \star \star} \\
(2.653)\end{array}$ & $\begin{array}{l}1.24^{\star \star} \\
(2.576)\end{array}$ & $\begin{array}{l}1.24^{\star \star *} \\
(2.747)\end{array}$ & $\begin{array}{l}1.21^{\star \star \star} \\
(2.596)\end{array}$ & $\begin{array}{l}1.24^{\star * \star} \\
(2.799)\end{array}$ \\
\hline Debt to GDP & $\begin{array}{c}0.99 \\
(-0.508)\end{array}$ & $\begin{array}{c}0.99 \\
(-0.511)\end{array}$ & $\begin{array}{c}0.99 \\
(-0.485)\end{array}$ & $\begin{array}{c}0.99 \\
(-0.520)\end{array}$ & $\begin{array}{c}1.00 \\
(-0.267)\end{array}$ & $\begin{array}{c}1.00 \\
(-0.349)\end{array}$ & $\begin{array}{c}0.99 \\
(-0.423)\end{array}$ & $\begin{array}{c}0.99 \\
(-0.463)\end{array}$ \\
\hline \multicolumn{9}{|l|}{ Macro Fundamentals } \\
\hline Output Gap & $\begin{array}{c}1.12 \\
(1.187)\end{array}$ & $\begin{array}{c}1.11 \\
(1.203)\end{array}$ & $\begin{array}{c}1.12 \\
(1.180)\end{array}$ & $\begin{array}{c}1.15 \\
(1.297)\end{array}$ & $\begin{array}{c}1.14 \\
(1.410)\end{array}$ & $\begin{array}{c}1.13 \\
(1.271)\end{array}$ & $\begin{array}{c}1.09 \\
(0.935)\end{array}$ & $\begin{array}{c}1.12 \\
(1.227)\end{array}$ \\
\hline Current Account to GDP & $\begin{array}{c}0.94 \\
(-0.800)\end{array}$ & $\begin{array}{c}0.94 \\
(-0.817)\end{array}$ & $\begin{array}{c}0.93 \\
(-0.854)\end{array}$ & $\begin{array}{c}0.93 \\
(-0.945)\end{array}$ & $\begin{array}{c}0.95 \\
(-0.563)\end{array}$ & $\begin{array}{c}0.96 \\
(-0.482)\end{array}$ & $\begin{array}{c}0.94 \\
(-0.821)\end{array}$ & $\begin{array}{c}0.94 \\
(-0.797)\end{array}$ \\
\hline Short-Term Real Rate & $\begin{array}{c}0.98 \\
(-0.185)\end{array}$ & $\begin{array}{c}0.97 \\
(-0.309)\end{array}$ & $\begin{array}{c}0.99 \\
(-0.132)\end{array}$ & $\begin{array}{c}0.98 \\
(-0.174)\end{array}$ & $\begin{array}{c}0.94 \\
(-0.616)\end{array}$ & $\begin{array}{c}0.97 \\
(-0.337)\end{array}$ & $\begin{array}{c}0.99 \\
(-0.119)\end{array}$ & $\begin{array}{c}0.98 \\
(-0.230)\end{array}$ \\
\hline \multicolumn{9}{|l|}{ Political-Institutional Variables } \\
\hline Post Elections & $\begin{array}{l}4.49^{* * *} \\
(2.686)\end{array}$ & $\begin{array}{l}4.67^{* * *} \\
(2.740)\end{array}$ & $\begin{array}{l}4.55^{* * *} \\
(2.707)\end{array}$ & $\begin{array}{l}4.63^{* \star \star *} \\
(2.769)\end{array}$ & $\begin{array}{l}4.15^{\star \star \star} \\
(2.871)\end{array}$ & $\begin{array}{l}4.67^{\star \star \star *} \\
(2.658)\end{array}$ & $\begin{array}{l}4.71^{* * *} \\
(2.761)\end{array}$ & $\begin{array}{l}4.48^{* * *} \\
(2.722)\end{array}$ \\
\hline Years Left in Current Term & $\begin{array}{l}1.65^{\star} \\
(1.873)\end{array}$ & $\begin{array}{l}1.67^{\star} \\
(1.857)\end{array}$ & $\begin{array}{l}1.65^{*} \\
(1.863)\end{array}$ & $\begin{array}{l}1.69^{\star \star} \\
(1.991)\end{array}$ & $\begin{array}{c}1.58^{*} \\
(1.761)\end{array}$ & $\begin{array}{c}1.64^{*} \\
(1.843)\end{array}$ & $\begin{array}{l}1.63^{*} \\
(1.773)\end{array}$ & $\begin{array}{l}1.65^{\star} \\
(1.836)\end{array}$ \\
\hline Political Polarization & $\begin{array}{c}0.59 \\
(-1.010)\end{array}$ & $\begin{array}{c}0.53 \\
(-1.065)\end{array}$ & $\begin{array}{c}0.60 \\
(-0.899)\end{array}$ & $\begin{array}{c}0.62 \\
(-0.967)\end{array}$ & $\begin{array}{c}0.59 \\
(-0.934)\end{array}$ & $\begin{array}{c}0.60 \\
(-0.882)\end{array}$ & $\begin{array}{c}0.56 \\
(-1.030)\end{array}$ & $\begin{array}{c}0.58 \\
(-0.963)\end{array}$ \\
\hline Fiscal Rule & $\begin{array}{c}3.20^{*} \\
(1.677)\end{array}$ & $\begin{array}{c}3.01 \\
(1.517)\end{array}$ & $\begin{array}{c}3.16 \\
(1.607)\end{array}$ & $\begin{array}{l}3.39^{*} \\
(1.796)\end{array}$ & $\begin{array}{c}3.20 \\
(1.473)\end{array}$ & $\begin{array}{c}3.01^{*} \\
(1.652)\end{array}$ & $\begin{array}{c}3.19 \\
(1.611)\end{array}$ & $\begin{array}{c}3.25^{*} \\
(1.720)\end{array}$ \\
\hline \multicolumn{9}{|l|}{ Indicators of Market Pressure } \\
\hline Rating Pressure & $\begin{array}{c}1.00 \\
(-0.006)\end{array}$ & & & & & & & \\
\hline Long-Term Bond Pressure & & $\begin{array}{c}0.34 \\
(-1.370)\end{array}$ & & & & & & \\
\hline Short-Term bond Pressure & & & $\begin{array}{c}0.82 \\
(-0.376)\end{array}$ & & & & & \\
\hline US $\$$ rate & & & & $\begin{array}{c}0.37 \\
(-0.965)\end{array}$ & & & & \\
\hline NEER & & & & & $\begin{array}{c}2.71^{*} \\
(1.782)\end{array}$ & & & \\
\hline EMP & & & & & & $\begin{array}{c}2.18 \\
(1.307)\end{array}$ & & \\
\hline Long-Term Sovereign Spread Pressure & & & & & & & $\begin{array}{l}2.53^{*} \\
(1.832)\end{array}$ & \\
\hline Short-Term Sovereign Spread Pressure & & & & & & & & $\begin{array}{c}1.26 \\
(0.313)\end{array}$ \\
\hline Observations & 450 & 450 & 450 & 450 & 450 & 450 & 450 & 450 \\
\hline R2 & 0.323 & 0.330 & 0.323 & 0.327 & 0.334 & 0.330 & 0.331 & 0.323 \\
\hline AIC & 238.7 & 237.0 & 238.6 & 237.7 & 236.2 & 237.0 & 236.9 & 238.6 \\
\hline Number of id & 17 & 17 & 17 & 17 & 17 & 17 & 17 & 17 \\
\hline
\end{tabular}

$1 /$ This table presents the results obtained from changing the identification strategy of market pressure episodes. In particular, the identification on z-scores above 2 based on the mean and standard deviation calculated over a rolling window of 36 months, and the monthly change is in the upper $90^{\text {th }}$ percentile of the cross-section of monthly change. See Box 2 for details on the identification of market pressure episodes. See notes to Table 4 and 5 for details on the indicators and definition of odd ratios. ${ }^{* * *} p<0.01,{ }^{* *} p<0.05,{ }^{*} p<0.1$.

(C) International Monetary Fund. Not for Redistribution 
Appendix II, Table 7. Interaction of Market Pressure Indicators and Debt to GDP 1/

\begin{tabular}{|c|c|c|c|c|c|c|c|c|}
\hline VARIABLES & $\begin{array}{c}(1) \\
\text { Downgrade }\end{array}$ & $\begin{array}{c}(2) \\
\text { LT Bond Market }\end{array}$ & $\begin{array}{c}\text { (3) } \\
\text { ST Bond Market }\end{array}$ & $\begin{array}{c}(4) \\
\text { Currency }\end{array}$ & $\begin{array}{c}(5) \\
\text { NEER }\end{array}$ & $\begin{array}{c}(6) \\
\text { EMP }\end{array}$ & $\begin{array}{c}(7) \\
\text { LT-Spread }\end{array}$ & $\begin{array}{c}(8) \\
\text { ST-Spread }\end{array}$ \\
\hline \multicolumn{9}{|l|}{ Fiscal Fundamentals } \\
\hline Primary Balance to GDP & $\begin{array}{l}0.75^{* \star *} \\
(-3.307)\end{array}$ & $\begin{array}{l}0.74^{* \star \star} \\
(-3.358)\end{array}$ & $\begin{array}{l}0.74^{* * *} \\
(-3.531)\end{array}$ & $\begin{array}{l}0.73^{* * *} \\
(-3.763)\end{array}$ & $\begin{array}{l}0.73^{* * *} \\
(-3.851)\end{array}$ & $\begin{array}{l}0.74^{* * *} \\
(-3.395)\end{array}$ & $\begin{array}{l}0.75^{* \star *} \\
(-3.335)\end{array}$ & $\begin{array}{c}0.74^{* * *} \\
(-3.506)\end{array}$ \\
\hline Debt-Stabilizing Primary Balance & $\begin{array}{l}1.19^{* *} \\
(2.037)\end{array}$ & $\begin{array}{l}1.25^{* \star \star *} \\
(2.646)\end{array}$ & $\begin{array}{l}1.26^{* * * *} \\
(2.879)\end{array}$ & $\begin{array}{l}1.28^{* * *} \\
(2.884)\end{array}$ & $\begin{array}{l}1.28^{* * *} \\
(2.755)\end{array}$ & $\begin{array}{l}1.22^{* * *} \\
(2.824)\end{array}$ & $\begin{array}{l}1.25^{* * *} \\
(2.621)\end{array}$ & $\begin{array}{l}1.23^{* * *} \\
(2.695)\end{array}$ \\
\hline Debt to GDP & $\begin{array}{c}0.99 \\
(-0.817)\end{array}$ & $\begin{array}{l}0.99 \\
(-0.507)\end{array}$ & $\begin{array}{c}1.00 \\
(-0.341)\end{array}$ & $\begin{array}{l}0.99 \\
(-0.438)\end{array}$ & $\begin{array}{c}1.00 \\
(-0.255)\end{array}$ & $\begin{array}{c}0.99 \\
(-0.527)\end{array}$ & $\begin{array}{c}1.00 \\
(-0.389)\end{array}$ & $\begin{array}{l}1.00 \\
(-0.378)\end{array}$ \\
\hline \multicolumn{9}{|l|}{ Macro Fundamentals } \\
\hline Output Gap & $\begin{array}{c}1.10 \\
(0.862)\end{array}$ & $\begin{array}{c}1.13 \\
(1.293)\end{array}$ & $\begin{array}{c}1.14 \\
(1.432)\end{array}$ & $\begin{array}{c}1.15 \\
(1.408)\end{array}$ & $\begin{array}{c}1.17 \\
(1.513)\end{array}$ & $\begin{array}{c}1.14 \\
(1.356)\end{array}$ & $\begin{array}{c}1.12 \\
(1.140)\end{array}$ & $\begin{array}{c}1.12 \\
(1.255)\end{array}$ \\
\hline Current Account to GDP & $\begin{array}{c}0.93 \\
(-0.971)\end{array}$ & $\begin{array}{c}0.95 \\
(-0.764)\end{array}$ & $\begin{array}{c}0.95 \\
(-0.571)\end{array}$ & $\begin{array}{c}0.93 \\
(-0.893)\end{array}$ & $\begin{array}{c}0.93 \\
(-0.942)\end{array}$ & $\begin{array}{c}0.96 \\
(-0.523)\end{array}$ & $\begin{array}{c}0.94 \\
(-0.773)\end{array}$ & $\begin{array}{l}0.94 \\
(-0.857)\end{array}$ \\
\hline Short-Term Real Rate & $\begin{array}{c}0.99 \\
(-0.083)\end{array}$ & $\begin{array}{c}0.97 \\
(-0.293)\end{array}$ & $\begin{array}{c}0.96 \\
(-0.391)\end{array}$ & $\begin{array}{c}1.00 \\
(-0.045)\end{array}$ & $\begin{array}{c}0.97 \\
(-0.331)\end{array}$ & $\begin{array}{c}0.98 \\
(-0.181)\end{array}$ & $\begin{array}{c}0.99 \\
(-0.125)\end{array}$ & $\begin{array}{l}0.99 \\
(-0.125)\end{array}$ \\
\hline \multicolumn{9}{|l|}{ Political-Institutional Variables } \\
\hline Post Elections & $\begin{array}{l}4.62^{\star \star \star} \\
(2.761)\end{array}$ & $\begin{array}{l}4.45^{\star \star \star *} \\
(2.808)\end{array}$ & $\begin{array}{l}4.22^{* *} \\
(2.473)\end{array}$ & $\begin{array}{l}4.77^{\star * * *} \\
(2.815)\end{array}$ & $\begin{array}{l}4.44^{\star \star \star *} \\
(2.814)\end{array}$ & $\begin{array}{l}4.63^{* \star \star} \\
(2.561)\end{array}$ & $\begin{array}{l}4.70^{* \star * *} \\
(2.731)\end{array}$ & $\begin{array}{l}4.45^{* \star \star *} \\
(2.638)\end{array}$ \\
\hline Years Left in Current Term & $1.66^{*}$ & $1.65^{*}$ & $1.61^{*}$ & $1.69^{* \star}$ & $1.61^{\star}$ & $1.69^{\star}$ & $1.66^{\star}$ & $1.65^{\star}$ \\
\hline Political Polarization & $\begin{array}{c}(1.928) \\
0.65\end{array}$ & $\begin{array}{c}(1.942) \\
0.58\end{array}$ & $\begin{array}{c}(1.760) \\
0.56\end{array}$ & $(2.027)$ & $(1.888)$ & $(1.937)$ & $(1.803)$ & $(1.867)$ \\
\hline Political Polarization & $(-0.920)$ & $(-0.924)$ & $(-1.005)$ & $\begin{array}{l}0.64 \\
(-0.857)\end{array}$ & $(-0.790)$ & $(-0.969)$ & $\begin{array}{c}0.56 \\
(-1.068)\end{array}$ & $(-0.988)$ \\
\hline Fiscal Rule & $\begin{array}{l}2.90 \\
(1.481)\end{array}$ & $\begin{array}{c}3.18 \\
(1.580)\end{array}$ & $\begin{array}{l}3.17^{\star} \\
(1.667)\end{array}$ & $\begin{array}{c}2.79 \\
(1.447)\end{array}$ & $\begin{array}{l}2.82 \\
(1.445)\end{array}$ & $\begin{array}{l}3.00 \\
(1.594)\end{array}$ & $\begin{array}{l}3.37^{\star} \\
(1.696)\end{array}$ & $\begin{array}{l}3.31^{\star} \\
(1.695)\end{array}$ \\
\hline \multicolumn{9}{|l|}{ Indicators of Market Pressure } \\
\hline Rating Pressure & $\begin{array}{c}0.11 \\
(-1.363)\end{array}$ & & & & & & & \\
\hline Rating Pressure*Debt to GDP & $\begin{array}{l}1.02 \\
(1.441)\end{array}$ & & & & & & & \\
\hline Long-Term Bond Pressure & & $\begin{array}{c}0.14 \\
(-1.056)\end{array}$ & & & & & & \\
\hline Long-Term Bond Pressure ${ }^{\star}$ Debt to GDP & & $\begin{array}{l}1.02 \\
(0.817)\end{array}$ & & & & & & \\
\hline Short-Term bond Pressure & & & $\begin{array}{c}3.56 \\
(1.068)\end{array}$ & & & & & \\
\hline Short-Term bond Pressure*Debt to GDP & & & $\begin{array}{c}0.98 \\
(-1.047)\end{array}$ & & & & & \\
\hline US \$ rate & & & & 1.75 & & & & \\
\hline US \$ Rate *Debt to GDP & & & & $\begin{array}{l}(0.555) \\
0.98\end{array}$ & & & & \\
\hline NEER & & & & $(-1.111)$ & 1.86 & & & \\
\hline NEER*Debt to GDP & & & & & $\begin{array}{c}(1.584) \\
0.99\end{array}$ & & & \\
\hline Terct & & & & & $(-1.613)$ & & & \\
\hline EMP & & & & & & 1.62 & & \\
\hline EMP*Debt to GDP & & & & & & $\begin{array}{l}1.00 \\
(0.453)\end{array}$ & & \\
\hline Long-Term Sovereign Spread Pressure & & & & & & & $\begin{array}{c}3.12 \\
(1.117)\end{array}$ & \\
\hline Long-Term Sovereign Spread Pressure* Debt to GDP & & & & & & & 0.99 & \\
\hline Short-Term Sovereign Spread Pressure & & & & & & & $(-0.703)$ & $\begin{array}{l}1.80 \\
(0.898)\end{array}$ \\
\hline Short-Term Sovereign Spread Pressure* Debt to GDP & & & & & & & & $\begin{array}{c}1.00 \\
(-0.565)\end{array}$ \\
\hline Observations & 450 & 450 & 450 & 450 & 450 & 450 & 450 & 450 \\
\hline R2 & 0.331 & 0.330 & 0.327 & 0.329 & 0.334 & 0.328 & 0.327 & 0.326 \\
\hline AIC & 238.7 & 239.0 & 239.7 & 239.2 & 238.1 & 239.5 & 239.7 & 240.0 \\
\hline Number of id & 17 & 17 & 17 & 17 & 17 & 17 & 17 & 17 \\
\hline
\end{tabular}

$1 /$ This table presents the results obtained from interacting market pressure indicators with the Debt to GDP. The identification of episodes is based on the values reported in the note to Table 6 . See notes to Table 4 and 5 for details on the indicators and definition of odd ratios. ${ }^{* * *} p<0.01,{ }^{* *} p<0.05,{ }^{*} p<0.1$. 


\section{Appendix II, Table 8. Splitting the Sample 1/}

(robust z-statistics in parentheses)

\begin{tabular}{|c|c|c|c|c|c|c|c|c|c|c|c|}
\hline VARIABLES & $\begin{array}{c}(1) \\
\text { No-AUS }\end{array}$ & $\begin{array}{c}(2) \\
\text { No-CAN }\end{array}$ & $\begin{array}{c}(3) \\
\text { No-DEU }\end{array}$ & $\begin{array}{c}(4) \\
\text { No-DNK }\end{array}$ & $\begin{array}{c}(5) \\
\text { No-ESP }\end{array}$ & $\begin{array}{c}(6) \\
\text { No-FIN }\end{array}$ & $\begin{array}{c}(7) \\
\text { No-FRA }\end{array}$ & $\begin{array}{c}(8) \\
\text { No-IRL }\end{array}$ & $\begin{array}{c}(9) \\
\text { No-ITA }\end{array}$ & $\begin{array}{c}(10) \\
\text { No-JPN }\end{array}$ & $\begin{array}{c}(11) \\
\text { No-SWE }\end{array}$ \\
\hline \multicolumn{12}{|l|}{ Fiscal Fundamentals } \\
\hline Primary Balance to GDP & $\begin{array}{l}0.74^{\star * *} \\
(-3.395)\end{array}$ & $\begin{array}{l}0.76^{\star * *} \\
(-3.101)\end{array}$ & $\begin{array}{c}0.72^{\star * *} \\
(-3.235)\end{array}$ & $\begin{array}{l}0.77^{* * *} \\
(-2.975)\end{array}$ & $\begin{array}{l}0.78^{* * *} \\
(-3.077)\end{array}$ & $\begin{array}{l}0.71^{* * *} \\
(-3.090)\end{array}$ & $\begin{array}{c}0.76^{\star * *} \\
(-3.126)\end{array}$ & $\begin{array}{l}0.75^{\star \star *} \\
(-3.292)\end{array}$ & $\begin{array}{l}0.74^{* * *} \\
(-2.813)\end{array}$ & $\begin{array}{l}0.77^{\star * *} \\
(-3.145)\end{array}$ & $\begin{array}{l}0.73^{* * *} \\
(-2.898)\end{array}$ \\
\hline Debt-Stabilizing Primary Balance & $\begin{array}{c}1.23^{* *} \\
(2.534)\end{array}$ & $\begin{array}{c}1.23^{* *} \\
(2.396)\end{array}$ & $\begin{array}{l}1.28^{* * *} \\
(3.334)\end{array}$ & $\begin{array}{l}1.27^{* * *} \\
(3.573)\end{array}$ & $\begin{array}{l}1.21^{* *} \\
(2.426)\end{array}$ & $\begin{array}{c}1.24^{* *} \\
(2.436)\end{array}$ & $\begin{array}{l}1.21^{* * *} \\
(2.614)\end{array}$ & $\begin{array}{l}1.23^{* * *} \\
(2.720)\end{array}$ & $\begin{array}{c}1.21 \\
(1.504)\end{array}$ & $\begin{array}{l}1.27^{* * *} \\
(2.854)\end{array}$ & $\begin{array}{c}1.22^{\star *} \\
(2.531)\end{array}$ \\
\hline Debt to GDP & $\begin{array}{c}0.99 \\
(-0.596)\end{array}$ & $\begin{array}{c}0.99 \\
(-0.493)\end{array}$ & $\begin{array}{c}0.99 \\
(-0.882)\end{array}$ & $\begin{array}{c}0.99 \\
(-0.784)\end{array}$ & $\begin{array}{c}1.00 \\
(-0.307)\end{array}$ & $\begin{array}{c}1.00 \\
(-0.016)\end{array}$ & $\begin{array}{c}1.00 \\
(-0.341)\end{array}$ & $\begin{array}{c}1.00 \\
(-0.359)\end{array}$ & $\begin{array}{c}0.99 \\
(-0.383)\end{array}$ & $\begin{array}{c}1.00 \\
(0.082)\end{array}$ & $\begin{array}{c}1.00 \\
(0.432)\end{array}$ \\
\hline \multicolumn{12}{|l|}{ Macro Fundamentals } \\
\hline Output Gap & $\begin{array}{c}1.08 \\
(0.852)\end{array}$ & $\begin{array}{c}1.13 \\
(1.280)\end{array}$ & $\begin{array}{c}1.17^{*} \\
(1.723)\end{array}$ & $\begin{array}{c}1.08 \\
(0.842)\end{array}$ & $\begin{array}{c}1.05 \\
(0.476)\end{array}$ & $\begin{array}{c}1.14 \\
(1.219)\end{array}$ & $\begin{array}{c}1.10 \\
(1.036)\end{array}$ & $\begin{array}{c}1.09 \\
(0.881)\end{array}$ & $\begin{array}{c}1.11 \\
(1.032)\end{array}$ & $\begin{array}{c}1.14 \\
(1.344)\end{array}$ & $\begin{array}{c}1.13 \\
(1.290)\end{array}$ \\
\hline Current Account to GDP & $\begin{array}{c}0.93 \\
(-0.872)\end{array}$ & $\begin{array}{c}0.95 \\
(-0.543)\end{array}$ & $\begin{array}{c}0.90 \\
(-1.075)\end{array}$ & $\begin{array}{c}0.95 \\
(-0.634)\end{array}$ & $\begin{array}{c}0.91 \\
(-1.046)\end{array}$ & $\begin{array}{c}0.97 \\
(-0.352)\end{array}$ & $\begin{array}{c}0.93 \\
(-0.857)\end{array}$ & $\begin{array}{c}0.95 \\
(-0.653)\end{array}$ & $\begin{array}{c}0.92 \\
(-0.974)\end{array}$ & $\begin{array}{c}0.96 \\
(-0.545)\end{array}$ & $\begin{array}{c}0.88^{*} \\
(-1.778)\end{array}$ \\
\hline Short-Term Real Rate & $\begin{array}{c}1.01 \\
(0.095)\end{array}$ & $\begin{array}{c}1.04 \\
(0.463)\end{array}$ & $\begin{array}{c}0.92 \\
(-0.757)\end{array}$ & $\begin{array}{c}0.97 \\
(-0.315)\end{array}$ & $\begin{array}{c}0.97 \\
(-0.302)\end{array}$ & $\begin{array}{c}0.93 \\
(-0.591)\end{array}$ & $\begin{array}{c}0.98 \\
(-0.189)\end{array}$ & $\begin{array}{c}0.97 \\
(-0.262)\end{array}$ & $\begin{array}{c}1.00 \\
(0.041)\end{array}$ & $\begin{array}{c}0.99 \\
(-0.142)\end{array}$ & $\begin{array}{c}0.95 \\
(-0.452)\end{array}$ \\
\hline \multicolumn{12}{|l|}{ Political-Institutional Variables } \\
\hline Post Elections & $\begin{array}{l}4.89^{* * *} \\
(2.710)\end{array}$ & $\begin{array}{c}3.72^{* *} \\
(2.346)\end{array}$ & $\begin{array}{l}5.03^{* * *} \\
(2.755)\end{array}$ & $\begin{array}{l}4.40^{* * *} \\
(2.709)\end{array}$ & $\begin{array}{l}5.18^{* * *} \\
(3.122)\end{array}$ & $\begin{array}{l}5.55^{* * *} \\
(2.989)\end{array}$ & $\begin{array}{l}3.47^{* * *} \\
(2.589)\end{array}$ & $\begin{array}{l}4.35^{\star * *} \\
(2.665)\end{array}$ & $\begin{array}{l}6.66^{* * *} \\
(3.820)\end{array}$ & $\begin{array}{c}4.61^{* *} \\
(2.365)\end{array}$ & $\begin{array}{l}4.67^{* * *} \\
(2.634)\end{array}$ \\
\hline Years Left in Current Term & $\begin{array}{c}1.64 \\
(1.643)\end{array}$ & $\begin{array}{c}1.87^{* *} \\
(2.057)\end{array}$ & $\begin{array}{c}1.65^{*} \\
(1.694)\end{array}$ & $\begin{array}{c}1.60 \\
(1.643)\end{array}$ & $\begin{array}{c}1.61^{*} \\
(1.671)\end{array}$ & $\begin{array}{c}1.68^{*} \\
(1.721)\end{array}$ & $\begin{array}{c}1.53 \\
(1.564)\end{array}$ & $\begin{array}{c}1.61^{*} \\
(1.702)\end{array}$ & $\begin{array}{l}2.06^{* * *} \\
(2.806)\end{array}$ & $\begin{array}{c}1.71^{*} \\
(1.701)\end{array}$ & $\begin{array}{c}1.70^{*} \\
(1.820)\end{array}$ \\
\hline Political Polarization & $\begin{array}{c}0.64 \\
(-0.664)\end{array}$ & $\begin{array}{c}0.54 \\
(-1.248)\end{array}$ & $\begin{array}{c}0.43 \\
(-1.442)\end{array}$ & $\begin{array}{c}0.50 \\
(-1.294)\end{array}$ & $\begin{array}{c}0.56 \\
(-0.889)\end{array}$ & $\begin{array}{c}0.56 \\
(-1.022)\end{array}$ & $\begin{array}{c}0.45 \\
(-1.303)\end{array}$ & $\begin{array}{c}0.56 \\
(-1.018)\end{array}$ & $\begin{array}{c}0.96 \\
(-0.077)\end{array}$ & $\begin{array}{c}0.64 \\
(-0.830)\end{array}$ & $\begin{array}{c}0.55 \\
(-1.023)\end{array}$ \\
\hline Fiscal Rule & $\begin{array}{l}5.93^{\star * *} \\
(3.449)\end{array}$ & $\begin{array}{c}3.20 \\
(1.203)\end{array}$ & $\begin{array}{c}4.09^{\star *} \\
(1.980)\end{array}$ & $\begin{array}{c}3.29^{*} \\
(1.692)\end{array}$ & $\begin{array}{c}2.93 \\
(1.517)\end{array}$ & $\begin{array}{c}3.90^{*} \\
(1.933)\end{array}$ & $\begin{array}{c}3.65^{*} \\
(1.787)\end{array}$ & $\begin{array}{c}3.33^{*} \\
(1.661)\end{array}$ & $\begin{array}{c}3.43^{*} \\
(1.694)\end{array}$ & $\begin{array}{c}3.08 \\
(1.493)\end{array}$ & $\begin{array}{l}4.16^{\star *} \\
(2.136)\end{array}$ \\
\hline Long-Term Sovereign Spread Pressure & $\begin{array}{c}1.82 \\
(1.340)\end{array}$ & $\begin{array}{c}1.87 \\
(1.294)\end{array}$ & $\begin{array}{c}1.54 \\
(1.017)\end{array}$ & $\begin{array}{c}1.82 \\
(1.470)\end{array}$ & $\begin{array}{c}1.72 \\
(1.128)\end{array}$ & $\begin{array}{c}1.86 \\
(1.424)\end{array}$ & $\begin{array}{c}1.83 \\
(1.350)\end{array}$ & $\begin{array}{c}1.46 \\
(0.916)\end{array}$ & $\begin{array}{c}1.60 \\
(1.022)\end{array}$ & $\begin{array}{c}1.73 \\
(1.413)\end{array}$ & $\begin{array}{c}2.00 \\
(1.548)\end{array}$ \\
\hline Observations & 429 & 420 & 432 & 421 & 421 & 420 & 420 & 439 & 420 & 420 & 422 \\
\hline $\mathrm{R} 2$ & 0.338 & 0.361 & 0.362 & 0.318 & 0.308 & 0.338 & 0.338 & 0.337 & 0.362 & 0.327 & 0.344 \\
\hline AIC & 228.1 & 219.2 & 221.0 & 235.3 & 228.3 & 227.1 & 230.6 & 232.3 & 216.5 & 229.5 & 226.1 \\
\hline Number of id & 17 & 17 & 17 & 17 & 17 & 17 & 17 & 17 & 17 & 17 & 17 \\
\hline
\end{tabular}

$1 /$ Columns "No-AUS", "No-CAN", etc., refers to estimation performed excluding the respective country from the sample. ${ }^{* * *} p<0.01,{ }^{* *} p<0.05,{ }^{*}$ $\mathrm{p}<0.1$. 


\section{Appendix II, Table 9. Determinants of a Consolidation Spell 1/}

\section{(robust z-statistics in parentheses)}

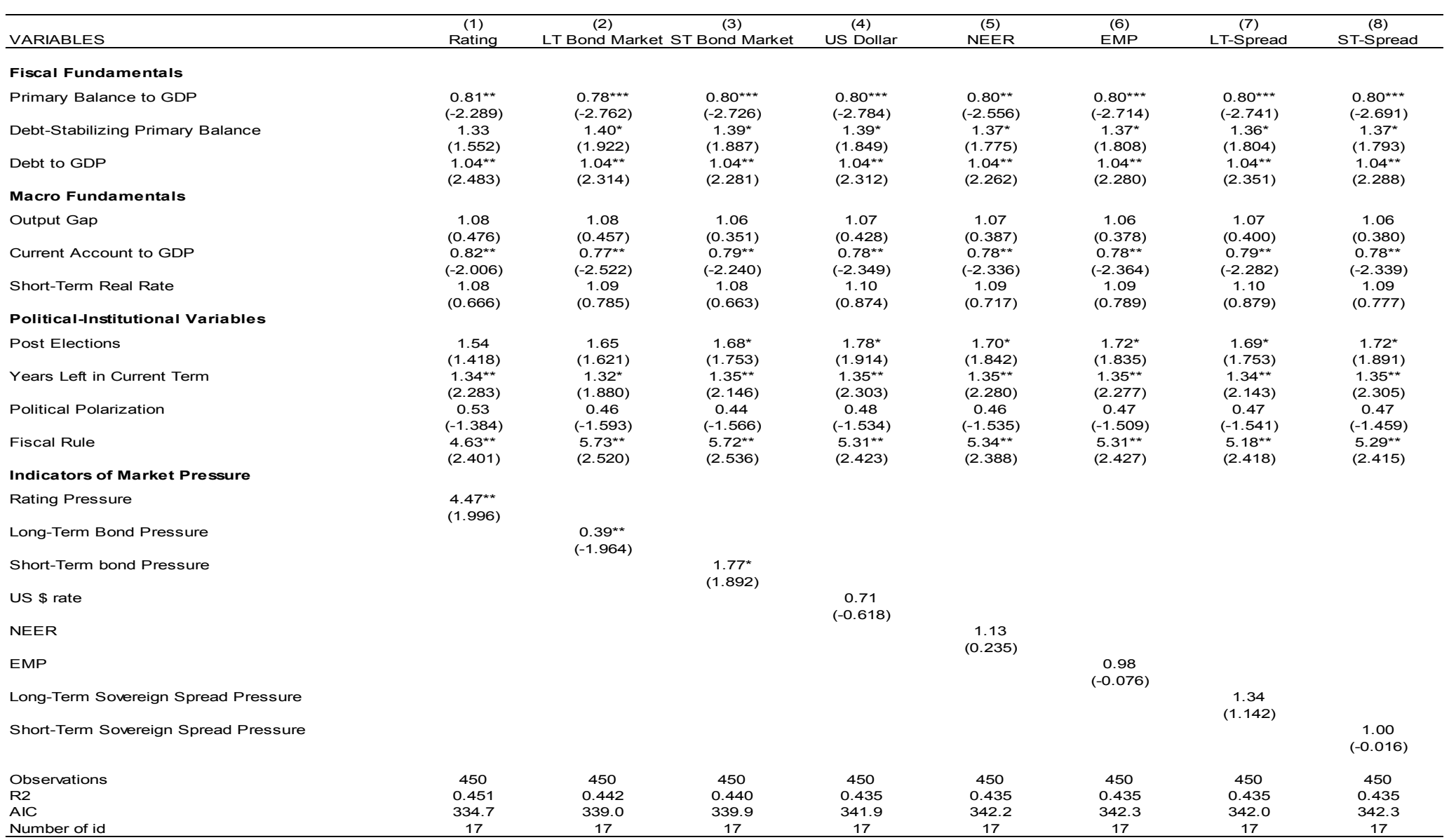

$1 /$ This table refers to the estimation using as dependent variable a dummy equal to one if a country is in a multi-year fiscal consolidation. See the Table 1 for definition of consolidation periods. ${ }^{* * *} p<0.01,{ }^{* *} p<0.05,{ }^{*} p<0.1$ 


\section{APPENDIX III. EXTENSION OF DEVRIES ET AL. (2011)}

In extending Devries et al. (2011) action-based fiscal consolidation dataset for the years 2010 and 2011, we sought to adhere to the original methodology to the extent possible. Devries and others (2011) use contemporaneous country-specific policy documents - produced by both national authorities and international institutions - to identify fiscal consolidation actions that were "motivated primarily by deficit reduction." These measures represent a response to past conditions and therefore are less likely to be systematically correlated with other ongoing economic developments.

The extension of the dataset was based mainly on the 2011 OECD report Restoring Public Finances, which outlines the economic situation, fiscal consolidation strategy, and major consolidation measures for each of the 30 member countries. The data presented within this report are largely drawn from the OECD Fiscal Consolidation Survey 2010 and supplemented by national authorities. The "Fiscal Consolidation Strategy" section in each chapter laid out each government's rationale for pursuing fiscal adjustment and was used to identify consolidation episodes that were motivated by a desire for deficit reduction. Finally, the "Major Consolidation Measures" section was used to determine the amount of planned fiscal consolidation, in percent of GDP, to be implemented in 2010 and 2011. Table 10 summarizes the narrative evidence used to identify consolidation episodes in 2010-11. The results are similar to those in Ağca and Igan (2013). 


\section{APPENDIX III, Table 10. Extending the Action-Based Dataset on Discretionary Fiscal Consolidations, 2010-11}

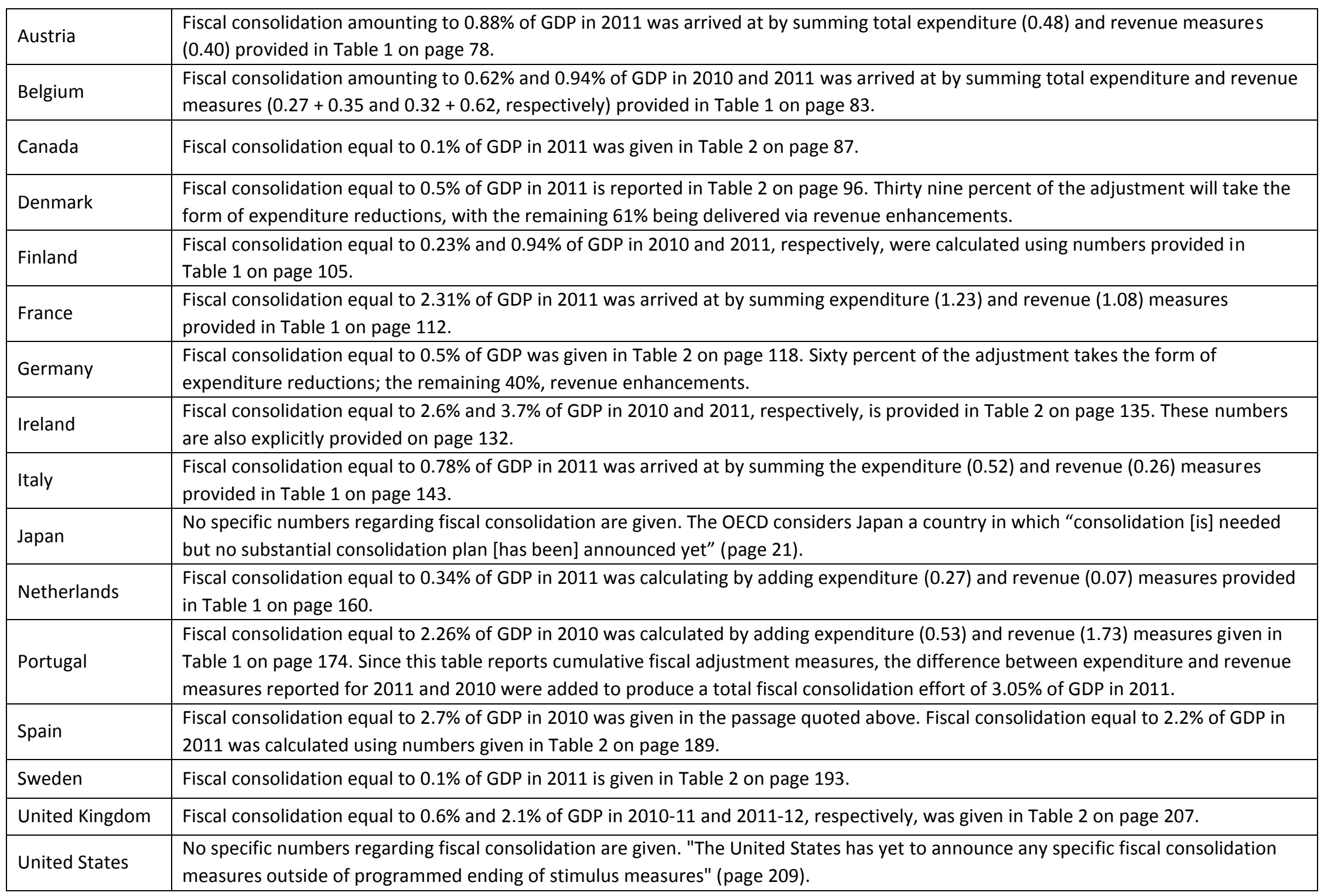




\section{DATA APPENDIX}

OECD countries (17)

Australia, Austria, Belgium, Canada, Denmark, Finland, France, Germany, Ireland, Italy, Japan, the Netherlands, Portugal, Spain, Sweden, the United Kingdom, the United States.

Data series used are:

\begin{tabular}{|l|l|l|}
\hline \multicolumn{1}{|c|}{ Variable } & \multicolumn{1}{|c|}{ Source } & \multicolumn{1}{c|}{ Definition } \\
\hline Primary Balance & OECD & General Government Primary Balance in percent of GDP \\
\hline $\begin{array}{l}\text { Debt-Stabilizing } \\
\text { Primary Balance }\end{array}$ & OECD & $\begin{array}{l}\text { (Nominal Effective interest rate- GDP deflator } \\
\text { inflation)/(1+Real growth) * Lagged Debt to GDP }\end{array}$ \\
\hline Debt to GDP & OECD & General Government Gross Debt to GDP \\
\hline Output Gap & OECD & Output Gap in percent of potential output \\
\hline Current Account & OECD & Current Account in percent of GDP \\
\hline Election & DPI & Legislative or Executive Election \\
\hline $\begin{array}{l}\text { Years Left in Current } \\
\text { Term }\end{array}$ & DPI & $\begin{array}{l}\text { Remaining years in the current legislation for the } \\
\text { government in charge }\end{array}$ \\
\hline Polarization & DPI & $\begin{array}{l}\text { Maximum polarization between the executive party and } \\
\text { the four principle parties of the legislation. }\end{array}$ \\
\hline Fiscal Rule & IMF & $\begin{array}{l}\text { Dummy equal one if the country has either: an } \\
\text { Expenditure Rule, Revenue Rule, Balanced Budget Rule, } \\
\text { Debt Rule. }\end{array}$ \\
\hline Long Term Bond Rate & IFS & Nominal Long-Term interest rate \\
\hline Short Term Bond & IFS & Nominal Short-Term interest rate \\
\hline NEER & BIS & Nominal Effective Exchange Rate \\
\hline Reserves & Haver & Foreign Exchange Reserves \\
\hline Ratings & S\&P, Moody's & Sovereign Outlook or Sovereign Rating Downgrades. \\
\hline
\end{tabular}

Sources: OECD, Economic Outlook n.90; DPI, Database of Political Institutions, 2010, World Bank; International Financial Statistics (IFS). 